\title{
A pollen-climate calibration from western Patagonia for palaeoclimatic reconstructions
}

\author{
Montade Vincent ${ }^{1,}{ }^{*}$, Peyron Odile ${ }^{2}$, Favier Charly ${ }^{2}$, Francois Jean Pierre ${ }^{3}$, Haberle Simon G. ${ }^{4,5}$
}

${ }^{1}$ Georg August Univ Gottingen, Albrecht von Haller Inst Plant Sci, Dept Palynol \& Climate Dynam, Gottingen, Germany.

2 Univ Montpellier, ISEM, CNRS, EPHE,IRD, Montpellier, France.

3 Univ Playa Ancha, Fac Ciencias Nat \& Exactas, Dept Ciencias Geog, Valparaiso, Chile.

${ }^{4}$ Australian Natl Univ, Dept Archaeol \& Nat Hist, Sch Culture Hist \& Language, Coll Asia \& Pacific, Canberra, ACT, Australia.

${ }^{5}$ Australian Natl Univ, ARC Ctr Excellence Australian Biodivers \& Heritag, Canberra, ACT, Australia.

*Corresponding author : Vincent Montade, email address : vincent.montade@gmail.com

\begin{abstract}
:
Palaeoecological studies of sediment records from the western margins of southern South America have revealed vegetation dynamics to be under the influence of major regional climate drivers such as the Southern Westerly Winds, Southern Annular Mode and El Nino Southern Oscillation. Despite the substantial number of palynological records in this region, very few quantitative pollen-based climate reconstructions using surface samples have been made. In this context, our objective was first to investigate the modern pollen-vegetation-climate relationships in the western Patagonian. The results show that the modern pollen dataset reflects the main vegetation types and that summer precipitation and winter temperature represent the main climate parameters controlling vegetation distribution. Secondly using this pollen-climate dataset we evaluate and compare the performance of two models (Weighted Averaging Partial Least Squares and Modern Analog Technique). We used these models to make climate reconstructions from two oceanic pollen records from western Patagonia. Compared with independent climate indicators, our pollen-inferred climate reconstructions reveal the same overall trends, showing the potential of pollen-climate transfer functions applied to this region. This study provides much needed data for quantitative climate reconstructions in South America, but which also needs to be improved by enlarging the modern pollen dataset.
\end{abstract}

Keywords : palaeoclimate, pollen, quantitative climate reconstruction, South America, western Patagonia 


\section{Introduction}

The latitudinal distribution of the main plant communities in western Patagonia closely follows the climate gradient across the region (Schmithüsen, 1956; Gajardo, 1994). In addition to temperatures decreasing southward, rainfall shows a strong increase southward directly related to the intensity of the Southern Westerly Wind (SWW) belt (Garreaud et al., 2013). In particular, models and palaeoclimate archives reveal the importance of the SWW belt through their role in regional climate change, alongside the growing recognition of the role of the Southern Annular Mode and El Niño Southern Oscillation phenomenon in modulating regional climate through time (e.g. Toggweiler et al., 2006; Anderson et al., 2009; Moreno et al., 2014). A substantial number of records based on palynological studies have thus been produced in this region with a focus on questions regarding the behaviour of the SWW belt at different timescales (see Flantua et al., 2015 and literature therein). Western Patagonia is one of the regions from South America with the most pollen records and these studies have sometimes led to different conclusions regarding the long-term dynamics of the SWW belt (e.g. Kilian and Lamy, 2012). To explain those discrepancies new records are required in regions where the density of palaeoecological data is lower, such as in the Chilean channel region $\left(47^{\circ}\right.$ to $\left.53^{\circ} \mathrm{S}\right)$. On the other hand, to explain those discrepancies, it also requires improvement of the methods to reconstruct the climate. Indeed, most palaeodata from this region are based on qualitative climate reconstructions, which may limit the interpretation of multi-site comparisons for reconstructing climate variability at a regional scale. Quantitative climate approaches are thus needed to provide a better understanding of the regional pattern of climate changes. Such approaches are also essential to perform data-model comparisons improving our understanding of climate mechanisms and future climate changes (Harrison et al., 2016). In Patagonia, local modern pollen datasets have been published during the last two decades to study relationships between pollen, vegetation and sometimes climate 
(Haberle and Bennett, 2001; Paez et al., 2001; Markgraf et al., 2002; Tonello et al., 2008, 2009; Mancini et al., 2012; Schäbitz et al., 2013). Only three local quantitative climate reconstructions inferred from fossil pollen records have been provided using some of these datasets (Markgraf et al., 2002; Tonello et al., 2009; Schäbitz et al., 2013). Hence, further local studies calibrating the existing modern pollen data to perform quantitative reconstructions are necessary as a first step to large-scale regional climate reconstructions.

In this context our aim here is to compile modern pollen data from western Patagonia to investigate the modern pollen-vegetation-climate relationships and to develop climate transfer functions. We first assemble modern pollen samples to span the range of environmental values likely to be represented by the main different vegetation types from this region. Secondly, this paper aims to provide reliable quantitative estimates for seasonal climatic variables. Multiple methods for pollen-based climate reconstruction including most standard methods, the Weighted Averaging Partial Least Squares (WA-PLS) and the Modern Analog Technique (MAT) will be applied and compared. We finally use these models to perform quantitative climate reconstructions for the last deglaciation and the Holocene inferred from two pollen records: the core MD07-3104 in the Reloncaví Fjord at $41^{\circ} \mathrm{S}$ and the core MD073088 offshore Taitao Peninsula at $46^{\circ} \mathrm{S}$ (Montade et al., 2012, 2013).

\section{Environmental settings}

Western Patagonia represents the southern part of South America in Southern Chile extending from $41^{\circ}$ to $56^{\circ} \mathrm{S}$ (Fig. 1). The Andean Cordillera spreads from north to south with peaks rarely exceeding $3000 \mathrm{~m}$ asl. Along the coast, a secondary mountain range, the Coastal Range, is rapidly submerged south of $42^{\circ} \mathrm{S}$ which results in a complex system of fjords, channels and archipelagos. The combination of these mountain ranges with high-velocity SWW generates high orographic rainfall increasing southward with SWW intensity increase 
(Garreaud et al., 2013). During the austral winter the SWW belt spreads northward to $30^{\circ} \mathrm{S}$ but remains south of $46-47^{\circ} \mathrm{S}$ during the austral summer. In the northern part, precipitation primarily from winter rains, reaches around $2000 \mathrm{~mm} \cdot \mathrm{yr}^{-1}$. Southwards, seasonality of precipitation decreases and disappears south of $46^{\circ} \mathrm{S}$, where precipitation reaches values over $3000 \mathrm{~mm} \cdot \mathrm{yr}^{-1}$. East of the Andes, the annual amount of precipitation decreases rapidly to below $1000 \mathrm{~mm}$. The temperatures contrast with precipitation showing a weak annual seasonal variability with values remaining above freezing along the coast. However, with the altitude increase, temperature seasonality increases through the Andes. The climate is thus considered as temperate to cool-temperate and humid to hyper-humid from north to south at low elevation. East of the Andes, climate is generally dry and temperate to cool-temperate from north to south (Garreaud et al., 2009).

Vegetation communities in western Patagonia are considered to be strongly influenced by the gradient of increasing annual precipitation and decreasing annual temperature southward (Schmithüsen, 1956; Gajardo, 1994; Markgraf et al., 2002; Luebert and Pliscoff, 2004) (Fig. 1): (i) the Lowland Deciduous Forest, dominated by deciduous trees (i.e. Nothofagus obliqua, N. alpina), conifers (i.e. Saxegothaea conspiscua, Podocarpus salignus) and several broadleaf evergreen elements (i.e. Aetoxicon punctatum, Persea lingue); (ii) the Valdivian Rainforest, the most diversified Patagonian forest type, characterized by the codominance of evergreen trees (i.e. Nothofagus dombeyi) with a number of broadleaf evergreen elements (i.e. Eucryphia cordifolia, Aetoxicon punctatum, Caldcluvia paniculata, and several species of Myrtaceae); (iii) the North Patagonian Rainforest, dominated by several species of conifers (i.e. Fitzroya cupressoides, Pilgerodendron uviferum, Podocarpus nubigenus) with some Nothofagus and broadleaf species (i.e. Nothofagus dombeyi, N. nitida, N. betuloides, Weinmannia trichosperma); (iv) the Subantarctic Rainforest, characterized by the codominance of conifer and Nothofagus species (i.e. Pilgerodendron uviferum, Nothofagus 
nitida and N. betuloides); (v) also frequently associated with the Subantarctic Rainforest, the

121 Magellanic Moorland represented by an open plant community occurring under high precipitation is characterized by the predominance of peat-bog plants (i.e. Sphagnum magellanicum), cushion-bog species (Astelia pumila, Donatia fascicularis) with graminoid

124 taxa mainly represented by Cyperaceae or Juncaceae and shrubs (Ericaceae); (vi) the

125 Subantarctic Deciduous Forest, mainly represented by deciduous trees (i.e. Nothofagus

126 pumilio and $N$. antarctica) adapted to cold conditions is also associated with an increase 127 proportion of graminoids (grasses or sedges) characteristic of to the Andean high elevation 128 grassland which dominates the landscape above the treeline.

129 Along the altitudinal gradient in northern Patagonia, with increasing orographic precipitation

130 and decreasing temperatures, a similar sequence of vegetation distribution is observed except

131 for the Magellanic Moorland which cannot develop under sub-zero temperature values.

132 Finally, east of the Andes under dry conditions the Patagonian Steppe develops in the

133 lowlands. The Patagonian Steppe is dominated by herbs and shrubs mainly characterized by

134 Poaceae, Asteraceae, Cyperaceae, Solanaceae, Apiaceae and Chenopodiaceae.

\section{Material and methods}

\subsection{Modern pollen and climate datasets}

138 The modern pollen dataset was compiled using 24 oceanic surface sediments (Montade et al., 139 2011) and 186 terrestrial surface samples including 139 soils and 47 lakes (Haberle and 140 Bennett, 2001; Markgraf et al., 2002; Francois, 2014). Much of these surface samples belong 141 to the northern half of Patagonia, distributed inland on both sides of the Andes (Fig. 1 and

142 Table S1). Only two samples are located between $47^{\circ}$ and $52^{\circ} \mathrm{S}$ corresponding to oceanic 143 surface samples in the fjords. Further south, 19 samples are from islands within the fjords and 144 off-shore near Punta Arenas. After dataset compilation, a total of 78 pollen taxa was obtained 
145 (Table S2) by updating the pollen taxa nomenclature followed the harmonization from

146 Markgraf et al. (2002). To this initial harmonization, we added five pollen taxa related to 147 samples located more southward (Astelia, Caltha, Donatia, Lepidoceras, Luzuriaga) and 148 Asteraceae (except Artemisia) were merged in two groups: A. Asteroideae and A.

149 Cichorioideae. For most of these samples, the pollen sums reach values above 200. Only 11 150 samples have a sum between 100 and 200; however as the number of surface samples is 151 relatively limited, we decided to keep these samples in the dataset. Pollen percentages were 152 calculated on the basis of their respective pollen sums excluding Rumex and Polygonaceae as 153 these taxa are generally related to human impact (Heusser, 2003; Schäbitz et al., 2013). 154 Although characteristic of aquatic and wetland taxa some Cyperaceae species (sedges) are 155 also naturally abundant in the Magellanic Moorland or in high elevation grasslands (Markgraf 156 et al., 2002; Villa-Martínez et al., 2012). For that reason Cyperaceae was kept in the 157 calculation of the pollen sums. To remove noise for statistical analyses, the data matrix was 158 reduced to 38 taxa characterized by values above $2 \%$ in more than two samples. Furthermore, 159 in order to provide a better understanding of the relationships between pollen assemblages, 160 vegetation and climatic parameters from western Patagonia, statistical analyses were 161 performed on a modern pollen dataset of 183 samples, excluding 27 samples from the initial dataset (Table S1). We first excluded samples dominated by herbs or shrubs pollen taxa 163 located east of $71^{\circ} \mathrm{W}$ in northern half of Patagonia (north of $46^{\circ} \mathrm{S}$ ) that mainly corresponds to

164 Patagonian steppe controlled by the east-west climate Andean gradient. West of $71^{\circ} \mathrm{W}$ in 165 northern half of Patagonia, we also excluded samples dominated by herbs or shrubs which 166 correspond to samples influenced by human impact reflecting an open landscape vegetation at 167 low elevation sites $(<500 \mathrm{~m}$ asl). We then excluded samples associated with pollen taxa of 168 Magellanic Moorland from the same area, because their occurrences too far in the north 169 reflect local edaphic conditions. 
170 An unconstrained cluster analysis based on chord distance was performed on the 183 samples

171 to reveal similarities among pollen assemblages and to provide the order of surface samples

172 plotted in the pollen diagram (Fig. 2). The different pollen zones identified by the cluster

173 dendrogram have been ascribed to groups according to pollen assemblages and vegetation

174 types (Figs. 2 and 3). Climate data calculated at each surface sample location were extracted

175 from the WorldClim database (Hijmans et al., 2005). The present-day climate parameters

176 correspond to the annual precipitation sum $\left(\mathrm{P}_{\mathrm{ANN}}\right)$ and the precipitation sums during

177 December-January-February $\left(\mathrm{P}_{\mathrm{SUM}}\right)$ and June-July-August ( $\left.\mathrm{P}_{\text {WIN }}\right)$. Temperature values

178 correspond to the mean values of the same months $\left(\mathrm{T}_{\mathrm{ANN}}, \mathrm{T}_{\mathrm{SUM}}\right.$ and $\left.\mathrm{T}_{\mathrm{WIN}}\right)$. For each oceanic

179 sample, the closest on-shore climate values were calculated. In the Andes, because of the

180 limited spatial resolution, elevational climate values based on WorldClim differ sometimes

181 from the measured values by several hundred meters. As interpolated temperature values are

182 very sensitive to the altitudinal gradient, we corrected temperature values using a lapse rate

183 value of $0.6^{\circ} \mathrm{C}$ per $100 \mathrm{~m}$. Altitude discrepancies were found to be too small to have a

184 significant influence on precipitation estimates and no corrections have been done.

185 Based on the same modern pollen dataset, we carried out a Principal Component Analysis

186 (PCA) on square-root transformed pollen relative frequencies and projected climate variables

187 on it to determine if, and how, variation in pollen rain is related to climate patterns in western

188 Patagonia. Square-root transformation of relative frequencies is commonly used as it allows

189 variance stabilization and 'signal to noise' ratio maximization in the data (Prentice, 1980),

190 which is equivalent to an ordination of pollen spectra using the square chord distance.

191

192

\subsection{Quantitative climate reconstruction}

193 The quantitative climate reconstruction is based on a multiple method approach to test the

194 reliability of the methods for these complex environments and to provide an improved 
assessment of the uncertainties involved in palaeoclimate reconstructions. Using the $\mathrm{R}$

196 package RIOJA (Juggins, 2015), we used the MAT based on a comparison of past assemblages to modern pollen assemblages, and the WA-PLS which requires statistical calibration. These methods are frequently used in climate reconstruction with their own set of advantages and limitations; they were successfully used for the Holocene climate reconstructions from terrestrial and marine records (e.g. Peyron et al., 2011; Mauri et al., 2015; Ortega-Rosas et al., 2016). The MAT (Guiot, 1990) uses the squared-chord distance to determine the degree of similarity between samples with known climate parameters (modern pollen samples) to samples for which climate parameters are to be estimated (fossil pollen sample). The chord distance indicates the degree of dissimilarity between two pollen samples (small distance $=$ close analogues selected for the climate reconstruction). A minimum distance corresponding to a minimum 'analogue' threshold is established. Subsequently, each climate parameter is calculated for each fossil pollen assemblage as the weighted mean of the climate of the closest modern analogues. The WA-PLS method (ter Braak and Juggins, 1993) is a transfer function which assumes that the relationship between pollen percentages and 210 climate is unimodal. The modern pollen dataset used is considered a large matrix with $\mathrm{n}$ 211 dimensions, corresponding to each of the pollen taxa within the dataset. WA-PLS operates by compressing the overall data structure into latent variables. Several taxa are directly related to

213 climate parameters of interest. To avoid the co-linearity among the taxa, we can reduce the 214 matrix into a smaller number of components based on both linear predictors of the parameter 215 of interest and the residual structure of the data when those predictors are removed. The 216 modification of PLS proposed by ter Braak and Juggins (1993) requires transformation of the 217 initial dataset using weighted averaging along a gradient defined by the climate parameter of 218 interest, such that the pollen taxa that best define the climate gradient are weighted more 219 heavily than those that show little specificity to the gradient. Ter Braak and Juggins (1993) 
detail the importance of using cross validation to assess and select WA-PLS models and show

221 that statistics based on cross-validation provide more reliable measures of the true predictive ability of the transfer functions.

223 We then evaluate the performance of models using a leave-one-out cross-validation test 224 performed with the training set of 183 modern pollen samples (38 pollen taxa). We also test 225 the reliability of the transfer functions applied to oceanic pollen assemblages by 226 reconstructing the climate conditions from 24 oceanic surface sediment samples (these oceanic samples were previously removed from the 183 modern pollen-climate training set before to do this test). We further check the extent to which calibration may be affected by spatial autocorrelation using the R package PALAEOSIG (Telford, 2015). Finally we apply the models to two oceanic pollen records: the core MD07-3104 located at $41^{\circ} \mathrm{S}$ in the Reloncaví Fjord and the core MD07-3088 located at 46 $\mathrm{S}$ offshore Taitao Peninsula (Montade et al., 2012, 2013).

\section{Results and discussion}

\subsection{Vegetation-pollen-climate relationships}

236 The pollen spectra were divided into eleven zones according to the cluster analysis (Fig. 2). 237 Because of limitations of morphological pollen identifications, most of the pollen taxa include 238 several species, which explains the high proportion of some taxa in different pollen zones. In 239 particular, the most abundant one, Nothofagus dombeyi-type includes five tree species $(N$. 240 dombeyi, $N$. pumilio, $N$. antarctica, $N$. betuloides, $N$. nitida) growing in the different 241 Patagonian environments. Based on the fluctuations of this pollen type associated and the 242 dominant pollen taxa, we combined the pollen zones in six groups to reflect the main 243 vegetation types and their ecological affinity (Figs. 2 and 3). In the grassland group which 244 corresponds to three pollen zones, Nothofagus dombeyi-type remains below 20\%. Samples are 
generally dominated by at least one herbaceous taxon, reaching more than $25 \%$ (Poaceae,

246 Cyperaceae, Asteraceae Asteroideae or Apiaceae). Most of samples of this group occur in the

247 northern half of Patagonia in the Andes and correspond to an open landscape vegetation

248 characterized by high elevation grassland partly influenced by the Subantarctic Deciduous

249 Forest. Southward, samples that also corresponding to an open landscape vegetation are

250 associated with the Magellanic Moorland. Although characterized by different species, low

251 resolution pollen identification for non-arboreal taxa (mainly family) makes it difficult to

252 differentiate open vegetation between high elevation and lowland environments (Markgraf et

$253 a l ., 2002)$. Included in the same group, these samples from different environments reflect the

254 importance of precipitation variability (Fig. 3b) and winter temperatures, that are decreasing

255 with altitude or southward attaining low values in winter $\left(\sim 3^{\circ} \mathrm{C}\right)$. The Subantarctic Deciduous

256 Forest (SDF) group includes two pollen zones (Fig. 2), either dominated by N. dombeyi-type

257 (> 60\%) or co-dominated by N. dombeyi-type (> 50\%) and Cyperaceae (15-35\%). These

258 assemblages are mainly distributed across the Andean relief in the northern half of Patagonia

259 with precipitation slightly higher and temperatures slightly lower than for the grassland group.

260 Samples co-dominated by Cyperaceae generally occurred above $900 \mathrm{~m}$ asl showing the

261 influence of high elevation grassland. Several samples are also located in the southern part

262 and five of them are from the islands within the fjords west of the Andes with high yearly

263 precipitation (Fig. 3). With two pollen zones, the Valdivian Rainforest (VR) group is

264 characterized by $N$. dombeyi-type remaining generally lower than $30 \%$, accompanied by

265 significant amounts of arboreal taxa such as Myrtaceae, Saxegothaea, Podocarpus,

266 Weinmannia or Gevuina/Lomatia. Among herbaceous taxa only Poaceae reach values higher

267 than $10 \%$ in this group which could be partly induced by human impact in northwestern

268 Patagonia. Precipitation $\left(2150 \mathrm{~mm} \cdot \mathrm{yr}^{-1}\right)$ and annual temperatures $\left(10^{\circ} \mathrm{C}\right)$ in this region are

269 higher than in the two previous vegetation groups. The North Patagonian/Valdivian 
Rainforest (NPR/VR) group (one pollen zone) shows again high amounts of $N$. dombeyi-type

271 (> 50\%), however the tree taxa Podocarpus, Cupressaceae, Myrtaceae and Tepualia replace

272 herbaceous taxa in comparison with the SDF group. This group occurs in the northern half of

273 Patagonia throughout the Andes and along the coast with generally high amounts of 274 precipitation $\left(2300 \mathrm{~mm} \cdot \mathrm{yr}^{-1}\right)$ and annual temperatures around $9^{\circ} \mathrm{C}$. Only two samples from 275 this group occur south of this domain probably related to their high frequencies of conifers.

276 The North Patagonian/Subantarctic Rainforest (NPR/SR) group is represented by two pollen 277 zones. It differs from NPR/VR group by lower values of $N$. dombeyi-type $(<40 \%)$ at the 278 expense of Cupressaceae (max. up to 93\%), Podocarpus and Tepualia. Samples are located in 279 the same region than NPR/VR group with similar temperatures and slightly higher 280 precipitation $\left(2466 \mathrm{~mm} \cdot \mathrm{yr}^{-1}\right)$. Abundant in the NPR/VR and NPR/SR groups, the arboreal 281 pollen taxon Cupressaceae includes three conifers, Fitzroya cupressoides, Pilgerodendron uviferum and Austrocedrus chilensis. The last one grows under colder and drier conditions than $F$. cupressoides and $P$. uviferum which are characteristic of very humid conditions mainly west of the Andes. Consequently, as discussed by Markgraf et al. (2002), the Cupressaceae pollen taxon may introduce some noise in climatic values of these two groups.

286 In the Subantarctic Rainforest/Magellanic Moorland (SR/MM) group characterized by one 287 pollen zone, pollen assemblages are mostly characterized by herbaceous or shrubby taxa with 288 Ericales, Myzodendron, Astelia, Juncaceae and Caltha with N. dombeyi-type fluctuating 289 between 30 and 50\%. The pollen taxon Astelia characteristic of A. pumila only growing in the 290 Magellanic Moorland is a very good indicator of this vegetation type. This group only occurs 291 in southern Patagonia and the low seasonality of precipitation and temperature allows us to 292 distinguish this vegetation group from the other ones (Fig. 3).

293 Distribution of samples in the PCA diagram (Fig. 4b) along the axis-1 reflects the variation 294 from the vegetation in an open landscape (grassland and SR/MM groups) mixed with the SDF 
group to the rainforest groups. Along axis-2, the distribution of samples mainly reflects the 296 vegetation from the SR/MM, NPR/SR, NPR/VR groups to grassland and VR groups. 297 Projection of climatic parameters in the PCA shows that the axis-1 is mainly correlated with 298 temperatures while axis-2 is mainly correlated with precipitation (Fig. 4). In particular, the 299 highest $r^{2}$ for axis-1 and -2 corresponding to $\mathrm{T}_{\mathrm{WIN}}(0.55)$ and $\mathrm{P}_{\mathrm{SUM}}(0.47)$, respectively, 300 support the notion that parameters represent the main climatic limiting factors in western 301 Patagonia determining vegetation distribution. This result is not surprising considering the 302 vegetation distribution in western Patagonia which is characterized by a southward winter temperature decrease and a summer precipitation increase reducing rainfall seasonality (Fig. 1). A temperature decrease is also partly observed with altitude increase across the Andes in 305 the northern half of western Patagonia where the rainforests is replaced by the SDF 306 sometimes mixed with grasslands. Although we have a spatial gap in the sample distribution 307 between $47^{\circ}$ and $52^{\circ} \mathrm{S}$, corresponding to the region where Magellanic Moorland mixed with the Subantarctic Rainforest is found, we partly capture the regional pattern of vegetation and climate conditions from this part of Patagonia with the samples located further south along the coast $\left(52-53^{\circ} \mathrm{S}\right)$. In particular, under high annual rainfalls and a weak seasonality of

311 precipitation and temperatures, these samples reflect similar climate and vegetation conditions with the region located from $47^{\circ}$ to $48^{\circ} \mathrm{S}$.

\subsection{Model performance}

316 An important requirement in quantitative paleoenvironmental reconstruction is the need of a high-quality training set of modern samples. The training set should be (1) representative of

318 the likely range of variables, (2) of highest possible taxonomy detail, (3) of comparable quality and (4) from the same sedimentary environment (Brewer et al., 2013). The last point 
can be particularly discussed because, due to our limited set of modern pollen samples, we

321 decided to compile samples from different depositional environments (soil, lake and oceanic).

322 Different depositional environment and taphonomic processes mainly between terrestrial and oceanic samples could affect significantly our pollen assemblages. Oceanic samples in particular should reflect a more regional signal than the terrestrial ones. However, it has been shown that the pollen signal from oceanic samples in this region remains relatively local to 326 the vegetation from the nearby continental area (Montade et al., 2011). This is mainly explained by the local transport conditions: under strong westerlies blowing throughout the year, the aeolian sediment input (including pollen) to the ocean is minimized and the pollen are mainly brought by strong fluvial discharges coming from short rivers restricting the sediment provenance. Probably partly related to these specific local conditions, it did not 331 appear that these different depositional environments substantially affected pollen assemblages (Montade et al., 2011).

333 To test the reliability of the transfer functions applied to oceanic pollen assemblages, we 334 applied the WA-PLS and the MAT to the 24 oceanic surface sediment pollen samples, 335 considered here as "fossil samples" (Fig. S1). The comparison between reconstructed and 336 observed values for the main climatic limiting factor in western Patagonia, $\mathrm{P}_{\mathrm{SUM}}$ and $\mathrm{T}_{\mathrm{WIN}}$ 337 shows a higher $r^{2}$ for the WA-PLS (0.56 and 0.67) than for the MAT (0.37 and 0.31). These 338 correlations are explained by a general southward precipitation increase and temperature 339 decrease, evidenced by both, reconstructed and observed values. However, some differences 340 are observed. One of the most obvious concerns the reconstructed $\mathrm{P}_{\text {SUM }}$ values: while 341 observed $\mathrm{P}_{\mathrm{SUM}}$ reach maxima between $47^{\circ}$ and $52^{\circ} \mathrm{S}$, where the Subantarctic Rainforest mixed 342 with the Magellanic Moorland occurs, the reconstructed values are much lower than observed.

343 This may be explained by a lack of terrestrial samples between $47^{\circ}$ and $52^{\circ} \mathrm{S}$. In particular, 344 the oceanic pollen samples at these latitudes are reconstructed with terrestrial samples from 
345 Subantarctic Rainforest located to the north and not with the rainforest mixed with the 346 Magellanic Moorland growing under very wet conditions. Concerning $\mathrm{T}_{\mathrm{WIN}}$, north of $47^{\circ} \mathrm{S}$, 347 reconstructed values are almost all underestimated. A large part of the terrestrial pollen 348 dataset is located throughout the Andes, while the oceanic pollen dataset is located along the 349 coast. Consequently temperature seasonality higher in the Andes induces lower reconstructed $350 \mathrm{~T}_{\mathrm{WIN}}$ than observed temperature along the coast. Despite these differences, explained by a 351 lack of modern pollen samples, the MAT and the WA-PLS are able to reconstruct the general 352 pattern of north-south climate gradient from oceanic pollen samples. Furthermore these 353 results suggest that the WA-PLS seems more accurate than the MAT to reconstruct the overall 354 latitudinal climate trends through western Patagonia.

\subsubsection{Evaluation of the WA-PLS and the MAT models}

357 After the first test on the oceanic pollen samples, we analysed the performance of the MAT and the WA-PLS transfer functions using the total 183-training set with a leave-one-out crossvalidation. Prior to final model development, we checked for 'outliers', i.e. the modern pollen samples producing extreme values. Two outliers for $\mathrm{P}_{\text {SUM }}$ were identified in both, the MAT and the WA-PLS (Fig. S2). A third outlier was identified with $\mathrm{P}_{\mathrm{SUM}}$ reconstructed by the WAPLS showing a high negative value (ca. $-500 \mathrm{~mm}$ ). Such a value seems to be associated with a high percentage of Araucaria $(>40 \%)$ reflecting a local signal from the vegetation. These 364 three outliers were excluded from the training set. The final transfer functions was then 365 performed on a 180-training set (Table 1 and Fig. 5). The optimal number of components to 366 include in the WA-PLS model was assessed by a cross-validation following the procedure of ter Braak and Juggins (1993). A leave-one-out cross-validation has been selected here. A two component WA-PLS model was then selected on the basis of the low root mean square error of prediction (RMSEP), low maximum bias, and high $\mathrm{r}^{2}$ between observed and predicted 
values of $\mathrm{P}_{\mathrm{SUM}}$ and $\mathrm{T}_{\mathrm{WIN}}$ (Table 1). For the MAT, we retain the four nearest analogues for an 371 optimal reconstruction.

372 The performance of our models is summarized in the Table 1. The RMSEP of the WA-PLS 373 model is of ca. $164 \mathrm{~mm}$ for $\mathrm{P}_{\mathrm{SUM}}$ and ca. $1.6^{\circ} \mathrm{C}$ for $\mathrm{T}_{\mathrm{WIN}}$. The $\mathrm{r}^{2}$ between the observed climate 374 values and those predicted by the WA-PLS (MAT) model is $0.53(0.54)$ and $0.55(0.77)$ for $375 \mathrm{P}_{\text {SUM }}$ and $\mathrm{T}_{\mathrm{WIN}}$ respectively. Equivalent for $\mathrm{P}_{\mathrm{SUM}}$, the diagnostic statistics of MAT shows 376 better scores for $T_{\text {WIN }}$ mainly concerning the $r^{2}$. However, several studies suggest that MAT 377 may produce over-optimistic diagnostics when cross-validation is limited to leave-one-out 378 model (Telford and Birks, 2005). Low values of $\mathrm{T}_{\mathrm{WIN}}$ are overestimated with both methods, 379 particularly with the WA-PLS (Fig. 5). We also observed an underestimation of the high $\mathrm{P}_{\text {SUM }}$ 380 values, particularly with the MAT.

381 The calibration seems robust and adequately model taxa and their environments with lowest 382 possible error of prediction and the lowest bias values (Table 1). However, the good 383 performance of the methods and the high correlations between climatic variables may also be 384 discussed according to the potential problem of the spatial autocorrelation in transfer 385 functions pointed out by Telford and Birks (2005). Spatial autocorrelation is the tendency of 386 sites close to each other to resemble one another more than randomly selected sites. Telford 387 and Birks (2005) argued that the estimation of the performance and the predictive power of a 388 training set by cross-validation assume that the test set must be statistically independent of the 389 training set and that a cross-validation in the presence of spatial-autocorrelation seriously 390 violate this assumption as the samples are not always spatially and statistically independent. 391 Therefore, in case of strong autocorrelation, the RMSEP on cross validation is overoptimistic. 392 The importance of spatial autocorrelation in transfer functions evidenced by Telford and Birks 393 (2005) has been discussed by several authors (Telford and Birks, 2005; Guiot and de Vernal, 394 2007; Fréchette et al., 2008; Thompson et al., 2008). However, the problems of 
autocorrelation in evaluation models are rarely tested in transfer functions inferred from 396 pollen data (Fréchette et al., 2008; Cao et al., 2014; Tian Fang et al., 2014), although these analyses are essential to obtain a robust transfer function.

Therefore to check if spatial autocorrelation affects the western Patagonia training set we have used the graphical method developed by Telford and Birks (2009). We compare the performance of the WA-PLS and MAT as the training set size is reduced by deleting sites at random, and by deleting sites geographically and environmentally close to the test site in cross-validation (Fig. S3). In the case of autocorrelation, deleting geographically close sites will preferentially delete the best analogues, and worsen the performance statistics more than random deletion. If the observations are independent, deleting a given proportion of them should have the same effect regardless of how they are selected (Telford and Birks, 2009).

Our results suggest that the $r^{2}$ from deleting of geographical neighbourhood sites closely 407 follow the $\mathrm{r}^{2}$ from deleting the environmental neighbourhood sites indicating that $\mathrm{P}_{\mathrm{SUM}}$ and $408 \mathrm{~T}_{\mathrm{WIN}}$ are influenced by autocorrelation. The $\mathrm{r}^{2}$ scores strongly decrease after $40 \mathrm{~km}$ for $\mathrm{P}_{\text {SUM }}$ and after $80 \mathrm{~km}$ for $\mathrm{T}_{\text {WIN }}$ and suggest that $\mathrm{T}_{\mathrm{WIN}}$ seems to be less affected by autocorrelation

410 than $\mathrm{P}_{\mathrm{SUM}}$. This strong $\mathrm{r}^{2}$ decrease shows that if a large amount of sites are deleted from the 411 training set, the transfer functions are strongly affected by a lack of sample. This highlight the 412 limited size of our training set from a region characterized by a complex environmental and 413 vegetation gradient. In that case an enlarged dataset would be necessary to more rigorously 414 perform model cross-validation and to address more fully these problems of spatial 415 autocorrelation. However, another way to check the reliability of our models is to apply it to 416 fossil pollen data and to compare the signal with independent proxies. 
419 Here we applied the WA-PLS and the MAT to two oceanic pollen records, core MD07-3088 located at $46^{\circ} \mathrm{S}$ off Taitao Peninsula and core MD07-3104 located at $41^{\circ} \mathrm{S}$ in Reloncaví Fjord

421 (Figs. 1 and 6). Spanning the last deglaciation and the Holocene, pollen data from core MD07-3088 illustrate the development of the North Patagonian Rainforest, which is interrupted by an expansion of Magellanic Moorland during the Antarctic Cold Reversal 424 (ACR) (Montade et al., 2013). Located further north, the core MD07-3104 shows compositional changes of temperate rainforest indicating warm and dry conditions during the beginning of the Holocene and more climate variability from the mid-Holocene associated with a cooling trend and with an increase of precipitation (Montade et al., 2012). Although the climate reconstructions based on both models are consistent, the minor fluctuations indicated by the MAT do not evidence significant climate changes. As previously mentioned, 430 this confirms that the MAT seems less appropriate than the WA-PLS to provide reliable 431 climate reconstructions according to our modern pollen-climate dataset. For that reason, the 432 climate reconstructions discussed below are based on the WA-PLS results.

433 Before $18 \mathrm{kyr}$, results obtained from core MD07-3088 at $46^{\circ} \mathrm{S}$ indicate lower values than 434 modern ones for $\mathrm{P}_{\text {SUM }}(400-300 \mathrm{~mm})$ and $\mathrm{T}_{\text {WIN }}\left(\right.$ ca. $\left.3^{\circ} \mathrm{C}\right)$. However, before $18 \mathrm{kyr}$, these 435 results must be taken with caution given that during the late glacial, the pollen signal is 436 characterized by low pollen concentrations reflecting reduced or absent vegetation on the 437 adjacent land areas at a time, and the potential for non-analogue vegetation communities to be 438 present during the glacial and post-glacial transition, when glaciers were greatly expanded 439 compared to the present (Montade et al., 2013). Under these conditions an overrepresentation 440 of high producers of pollen such as Nothofagus trees was observed, which prevents local 441 vegetation reconstructions and which is likely to bias our climate reconstructions at that time. 442 From $18-17.5 \mathrm{kyr}$, a slight warming trend of $0.5^{\circ} \mathrm{C}$ is recorded, contemporaneous of the 443 beginning of the deglaciation evidenced by the $\delta \mathrm{D}$ variations of EPICA Dome $\mathrm{C}$ ice core (Fig. 
6d). Such a trend occurs simultaneously with the development of vegetation following the

445 retreat of glaciers recorded in the region (Bennett et al., 2000; Haberle and Bennett, 2004).

446 Recorded from the same core, the beginning of the last deglaciation is also well evidenced by

447 the increase of summer sea surface temperature (SSTs, Fig. 6c) reconstructed from 448 planktonic foraminifera assemblages (Siani et al., 2013). The strongest change evidenced by 449 our climate reconstruction correspond to a rapid $\mathrm{P}_{\text {SUM }}$ increase starting at $14.5 \mathrm{kyr}$ (ACR) with 450 maximum values between 800 and $1000 \mathrm{~mm}$. High $\mathrm{P}_{\text {SUM }}$ values persist up to the end of the 451 Younger Dryas (YD) period (Fig. 6c). Simultaneously, we observe a progressive $\mathrm{T}_{\mathrm{WIN}}$ 452 increase of ca. $2^{\circ} \mathrm{C}$ while for the SSTs, values stop to increase during the ACR then decrease 453 of $1^{\circ} \mathrm{C}$ at $13 \mathrm{kyr}$ before to reach maxima after the YD. This strong precipitation increase 454 characterised by very high values suggests an intensification of the SWW during the ACR and 455 the YD. Already recorded by previous studies from western Patagonia, this abrupt change was 456 interpreted as a northward shift of the SWW belt (García et al., 2012; Moreno et al., 2012; 457 Montade et al., 2015). Today, latitudes under the core of the SWW belt where rainfalls are 458 very high, the temperature seasonality is the lowest of western Patagonia and, because of 459 strong ocean influence, temperature values remain always positive at low elevation. 460 Consequently, after the last glacial conditions, such an intensification of SWW and 461 precipitation would have reduced the temperature seasonality inducing a milder summer and 462 winter temperature. This scenario might explain the observed $\mathrm{T}_{\mathrm{WIN}}$ increase by our 463 reconstruction. Based on this result, glacier advances evidenced in western Patagonia during 464 the ACR and the YD might be more related to hydrological changes than to a strong cooling 465 (Moreno et al., 2009; García et al., 2012; Glasser et al., 2012). However, additional 466 quantitative climate reconstructions are necessary to test this hypothesis.

467 After the $\mathrm{YD}, \mathrm{P}_{\mathrm{SUM}}$ reconstructed from core MD07-3088 decrease progressively to reach 468 present-day values between 400 and $500 \mathrm{~mm}$ (Fig. 6a). $\mathrm{T}_{\mathrm{WIN}}$ values $\left(\mathrm{ca} .6^{\circ} \mathrm{C}\right.$ ) are maxima 
during the early Holocene, before they slightly decrease and fluctuate between 5 and $6^{\circ} \mathrm{C}$, 470 close to modern values (Fig. 6c). This moderate change in comparison with the last 471 deglaciation are consistent with past vegetation dynamics recorded from the same latitude 472 showing that the North Patagonian Rainforest rapidly reaches its modern composition during 473 the early Holocene (Bennett et al., 2000). On the other hand, the core MD07-3104 indicates a 474 stronger climate variability during the Holocene. After reaching their maxima after the YD, $475 \mathrm{P}_{\text {SUM }}$ and $\mathrm{T}_{\mathrm{WIN}}$ decrease from 500 to $350 \mathrm{~mm}$ and from 11 to $8.5^{\circ} \mathrm{C}$ from the early to the mid476 Holocene (Figs. 6a and c). Then from $6 \mathrm{kyr}, \mathrm{P}_{\text {SUM }}$ and $\mathrm{T}_{\mathrm{WIN}}$ fluctuate around $400 \mathrm{~mm}$ and $9^{\circ} \mathrm{C}$ 477 before a slight decrease during the late Holocene to reach values close to the modern 478 conditions. The climate variability reconstructed from core MD07-3104 is compared with a 479 pollen index calculated from Lago Condorito located at ca. $30 \mathrm{~km}$ from the oceanic core 480 (Moreno, 2004; Moreno et al., 2010). Based on the normalized ratio between Eucryphia481 Caldcluvia and Podocarpus, positive values of this index reflect a warm-temperate, 482 seasonally dry climate with reduced SWW and negative values indicate cool-temperate and/or 483 wet conditions with enhanced SWW. While our reconstruction indicates that $\mathrm{T}_{\mathrm{WIN}}$ increase is 484 associated with $\mathrm{P}_{\text {SUM }}$ increase, the pollen index indicates warm-temperate conditions under 485 low precipitation (Fig. 6). This difference might be related to a different sensitivity of 486 seasonality between the pollen index and our reconstructed $\mathrm{T}_{\text {WIN }}$. On the other hand, 487 comparison of $\mathrm{P}_{\mathrm{SUM}}$ curve and the index reveals the same trend. Although a short time lag is 488 observed, which is certainly related to a problem of marine age reservoir from the oceanic 489 core (Montade et al., 2012), our P $\mathrm{P}_{\mathrm{SUM}}$ reconstruction supports the known dynamic of 490 precipitation and SWW changes in the region. Southward at $46^{\circ} \mathrm{S}$, such changes are not 491 recorded by our climate reconstruction and by vegetation changes (Montade et al., 2013). 492 Today the northern Patagonia at $41^{\circ} \mathrm{S}$ is characterized by a seasonally dry climate directly 493 connected with a strong seasonality of SWW intensity. In comparison, the location of core 
494 MD07-3088 closer to the position of the core of SWW already since the early Holocene, 495 under the persistent influence of the SWW, rainfalls are strong all over the year. 496 Consequently, this might explain why hydrological changes related to SWW changes would 497 have more impacted the northern Patagonia during the Holocene.

499 Conclusions

500 To conclude, although based on different depositional environments (soil, lake and ocean), 501 our modern pollen dataset (183 samples) from western Patagonia reflects the main vegetation 502 types distributed along the latitudinal and the altitudinal gradient. Investigating the modern 503 pollen-vegetation-climate relationships, we further demonstrate that the major vegetation 504 distribution reflected by pollen assemblages is mainly controlled by two parameters: $\mathrm{P}_{\text {SUM }}$ and $505 \mathrm{~T}_{\text {WIN }}$. Characterized by a southward $\mathrm{T}_{\text {WIN }}$ decrease and a southward $\mathrm{P}_{\text {SUM }}$ increase, these two 506 parameters represent the main climatic limiting factor in western Patagonia controlling the 507 latitudinal distribution of the vegetation. Based on the modern pollen dataset, we then 508 analysed and compared the performance of two standard methods: the MAT and the WA509 PLS. They adequately model taxa and their environments; however our results also reveal that 510 the WA-PLS is more suitable than the MAT which suffers of a lack of modern pollen samples 511 to perform reliable climate reconstructions. Using two oceanic cores from northern Patagonia 512 at $41^{\circ} \mathrm{S}$ and $46^{\circ} \mathrm{S}$ we finally proceeded to reconstructions of $\mathrm{P}_{\mathrm{SUM}}$ and $\mathrm{T}_{\mathrm{WIN}}$ values during the 513 late Glacial and the Holocene. The most important climate change occurred during ACR and 514 YD where $\mathrm{P}_{\text {SUM }}$ reach the double amount of modern values related to an enhanced SWW. 515 Although our results show several methodological limitations (mainly by using oceanic and 516 terrestrial samples together), our climate reconstructions, consistent with the regional climate 517 changes, illustrate the potential to develop quantitative methods in western Patagonia. 518 Representing one of the parts of South America with the most pollen records, additional 
quantitative climate reconstructions have to be performed to improve our understanding of

520 climate dynamic at a regional scale. Furthermore, the modern pollen dataset still needs to be 521 enlarged, to reduce uncertainties of climate reconstructions.

\section{Acknowledgements}

524 V.M. benefited from a postdoctoral position funded by Ecole Pratique des Hautes Etudes at 525 Institut des Sciences de l'Evolution de Montpellier (ISEM) and Deutsche 526 Forschungsgemeinschaft at Department of Palynology and Climate Dynamics from the 527 University of Goettingen. We thank Vera Markgraf for sharing pollen data and for helpful 528 comments on the first version of the manuscript. We also thank Elisabeth Michel and 529 Giuseppe Siani for sharing data concerning the oceanic core MD07-3088. Finally we are 530 particularly grateful from the very constructive comments from two anonymous referees 531 greatly improving this manuscript. This is an ISEM contribution $\mathrm{n}^{\circ} \mathrm{XX}$.

\section{References}

534 Anderson RF, Ali S, Bradtmiller LI, Nielsen SHH, Fleisher MQ, Anderson BE, Burckle LH. 2009. Wind-Driven Upwelling in the Southern Ocean and the Deglacial Rise in Atmospheric $\mathrm{CO}_{2}$. Science 323: 1443-1448.

537 Bennett KD, Haberle SG, Lumley SH. 2000. The Last Glacial-Holocene Transition in Southern Chile. Science 290: 325-328.

ter Braak CJF, Juggins S. 1993. Weighted averaging partial least squares regression (WAPLS): an improved method for reconstructing environmental variables from species assemblages. Hydrobiologia 269-270: 485-502. 
Brewer S, Guiot J, Barboni D. 2013. POLLEN METHODS AND STUDIES | Use of Pollen as Climate Proxies. In Encyclopedia of Quaternary Science (Second Edition), Elias SA, Mock CJ (eds). Elsevier: Amsterdam; 805-815.

Cao X, Herzschuh U, Telford RJ, Ni J. 2014. A modern pollen-climate dataset from China and Mongolia: Assessing its potential for climate reconstruction. Review of Palaeobotany and Palynology 211: 87-96.

Flantua SGA, Hooghiemstra H, Grimm EC, Behling H, Bush MB, González-Arango C, Gosling WD, Ledru M-P, Lozano-García S, Maldonado A, Prieto AR, Rull V, Van Boxel JH. 2015. Updated site compilation of the Latin American Pollen Database. Review of Palaeobotany and Palynology 223: 104-115.

Francois J-P. 2014. Postglacial paleoenvironmental history of the Southern Patagonian Fjords at $53^{\circ} \mathrm{S}$. PhD thesis. Universität zu Köln.

Fréchette B, de Vernal A, Guiot J, Wolfe AP, Miller GH, Fredskild B, Kerwin MW, Richard PJH. 2008. Methodological basis for quantitative reconstruction of air temperature and sunshine from pollen assemblages in Arctic Canada and Greenland. Quaternary Science Reviews 27: 1197-1216.

Gajardo R. 1994. La vegetación natural de Chile : clasificación y distribución geográfica. Santiago.

García JL, Kaplan MR, Hall BL, Schaefer JM, Vega RM, Schwartz R, Finkel R. 2012. Glacier expansion in southern Patagonia throughout the Antarctic cold reversal. Geology 40: 859-862.

Garreaud R, Lopez P, Minvielle M, Rojas M. 2013. Large-Scale Control on the Patagonian Climate. Journal of Climate 26: 215-230.

Garreaud RD, Vuille M, Compagnucci R, Marengo J. 2009. Present-day South American climate. Palaeogeography, Palaeoclimatology, Palaeoecology 281: 180-195. 
Glasser NF, Harrison S, Schnabel C, Fabel D, Jansson KN. 2012. Younger Dryas and early Holocene age glacier advances in Patagonia. Quaternary Science Reviews 58: 7-17.

Grieser J, Giommes R, Bernardi M. 2006. New_LocClim - the Local Climate Estimator of FAO. Geophysical Research Abstracts 8: 08305.

Guiot J. 1990. Methodology of the last climatic cycle reconstruction in France from pollen data. Palaeogeography, Palaeoclimatology, Palaeoecology 80: 49-69.

Guiot J, de Vernal A. 2007. Chapter Thirteen Transfer Functions: Methods for Quantitative Paleoceanography Based on Microfossils. In Developments in Marine Geology, Hillaire-Marcel C, de Vernal A. (eds). Elsevier: Amsterdam; 523-563.

Haberle SG, Bennett KD. 2001. Modern pollen rain and lake mud-water interface geochemistry along environmental gradients in southern Chile. Review of Palaeobotany and Palynology 117: 93-107.

Haberle SG, Bennett KD. 2004. Postglacial formation and dynamics of North Patagonian Rainforest in the Chonos Archipelago, Southern Chile. Quaternary Science Reviews 23: $2433-2452$.

Harrison SP, Bartlein PJ, Prentice IC. 2016. What have we learnt from palaeoclimate simulations? Journal of Quaternary Science 31: 363-385.

Heusser CJ. 2003. Ice age Southern Andes - A chronicle of paleoecological events. Elsevier: Amsterdam.

Hijmans RJ, Cameron SE, Parra JL, Jones PG, Jarvis A. 2005. Very high resolution interpolated climate surfaces for global land areas. International Journal of Climatology 25: 1965-1978.

Juggins PS. 2015. rioja: Analysis of Quaternary Science Data. http://eprints.ncl.ac.uk.

Kilian R, Lamy F. 2012. A review of Glacial and Holocene paleoclimate records from southernmost Patagonia $\left(49-55^{\circ} \mathrm{S}\right)$. Quaternary Science Reviews 53: 1-23. 
Lemieux-Dudon B, Blayo E, Petit J-R, Waelbroeck C, Svensson A, Ritz C, Barnola J-M, Narcisi BM, Parrenin F. 2010. Consistent dating for Antarctic and Greenland ice cores. Quaternary Science Reviews 29: 8-20.

Luebert F, Pliscoff P. 2004. Classification de pisios de vegetatacion y anlysis de representatividad ecologica de areas propuesta para la proteccion en la ecoregion valdivia. Santiago.

Mancini MV, de Porras ME, Bamonte FP. 2012. Southernmost South America Steppes: vegetation and its modern pollen-assemblages representation. In Steppe Ecosystem Dynamics, Land Use and Conservation, Germano D (ed). Nova Science Publishers: New York; 141-156.

Markgraf V, Webb RS, Anderson KH, Anderson L. 2002. Modern pollen/climate calibration for southern South America. Palaeogeography, Palaeoclimatology, Palaeoecology 181: 375-397.

Mauri A, Davis BAS, Collins PM, Kaplan JO. 2015. The climate of Europe during the Holocene: a gridded pollen-based reconstruction and its multi-proxy evaluation. Quaternary Science Reviews 112: 109-127.

Montade V, Combourieu-Nebout N, Chapron E, Mulsow S, Abarzúa AM, Debret M, Foucher A, Desmet M, Winiarski T, Kissel C. 2012. Regional vegetation and climate changes during the last $13 \mathrm{kyr}$ from a marine pollen record in Seno Reloncaví, southern Chile. Review of Palaeobotany and Palynology 181: 11-21.

Montade V, Combourieu-Nebout N, Kissel C, Haberle SG, Siani G, Michel E. 2013. Vegetation and climate changes during the last 22,000 yr from a marine core near Taitao Peninsula, southern Chile. Palaeogeography, Palaeoclimatology, Palaeoecology 369: 335-348. 
616 Montade V, Combourieu-Nebout N, Kissel C, Mulsow S. 2011. Pollen distribution in marine surface sediments from Chilean Patagonia. Marine Geology 282: 161-168.

618 Montade V, Kageyama M, Combourieu-Nebout N, Ledru M-P, Michel E, Siani G, Kissel C. 2015. Teleconnection between the Intertropical Convergence Zone and southern westerly winds throughout the last deglaciation. Geology 43: 735-738.

Moreno PI. 2004. Millennial-scale climate variability in northwest Patagonia over the last 15 000 yr. Journal of Quaternary Science 19: 35-47.

Moreno PI, Francois JP, Moy CM, Villa-Martínez R. 2010. Covariability of the Southern Westerlies and atmospheric $\mathrm{CO}_{2}$ during the Holocene. Geology 38: 727-730. cold conditions until 11.5 ka in southwestern Patagonia. Geology 37: 375-378.

Moreno PI, Vilanova I, Villa-Martínez R, Garreaud RD, Rojas M, De Pol-Holz R. 2014. Southern Annular Mode-like changes in southwestern Patagonia at centennial timescales over the last three millennia. Nature Communications 5: 4375.

631 Moreno PI, Villa-Martínez R, Cárdenas ML, Sagredo EA. 2012. Deglacial changes of the southern margin of the southern westerly winds revealed by terrestrial records from SW Patagonia (52 S). Quaternary Science Reviews 41: 1-21.

634 Ortega-Rosas CI, Peñalba MC, Guiot J. 2016. The Lateglacial interstadial at the southeastern limit of the Sonoran Desert, Mexico: vegetation and climate reconstruction based on pollen sequences from Ciénega San Marcial and comparison with the subrecent

638 Paez MM, Schäbitz F, Stutz S. 2001. Modern pollen-vegetation and isopoll maps in southern 
640 Peyron O, Goring S, Dormoy I, Kotthoff U, Pross J, de Beaulieu J-L, Drescher-Schneider R, Vannière B, Magny M. 2011. Holocene seasonality changes in the central Mediterranean region reconstructed from the pollen sequences of Lake Accesa (Italy) and Tenaghi Philippon (Greece). The Holocene 21: 131-146.

Prentice IC. 1980. Multidimensional scaling as a research tool in quaternary palynology: A review of theory and methods. Review of Palaeobotany and Palynology 31: 71-104.

Schäbitz F, Wille M, Francois J-P, Haberzettl T, Quintana F, Mayr C, Lücke A, Ohlendorf C, Mancini V, Paez MM, Prieto AR, Zolitschka B. 2013. Reconstruction of palaeoprecipitation based on pollen transfer functions - the record of the last $16 \mathrm{ka}$ from Laguna Potrok Aike, southern Patagonia. Quaternary Science Reviews 71: 175190.

Schmithüsen J. 1956. Die räumliche Ordnung der chilenischen Vegetation. Bonner Geographische Abhandlungen 17: 1-86.

Siani G, Michel E, De Pol-Holz R, DeVries T, Lamy F, Carel M, Isguder G, Dewilde F, Lourantou A. 2013. Carbon isotope records reveal precise timing of enhanced Southern Ocean upwelling during the last deglaciation. Nature Communications 4.

Telford RJ. 2015. palaeoSig: Significance Tests for Palaeoenvironmental Reconstructions.

Telford RJ, Birks HJB. 2005. The secret assumption of transfer functions: problems with spatial autocorrelation in evaluating model performance. Quaternary Science Reviews 24: 2173-2179.

Telford RJ, Birks HJB. 2009. Evaluation of transfer functions in spatially structured environments. Quaternary Science Reviews 28: 1309-1316.

Thompson RS, Anderson KH, Bartlein PJ. 2008. Quantitative estimation of bioclimatic parameters from presence/absence vegetation data in North America by the modern analog technique. Quaternary Science Reviews 27: 1234-1254. 
665 Tian F, Herzschuh U, Telford RJ, Mischke S, Van der Meeren T, Krengel M, Richardson J.

666

667

668

669

670

671

672

673

674

675

676

677

678

679 2014. A modern pollen-climate calibration set from central-western Mongolia and its application to a late glacial-Holocene record. Journal of Biogeography 41: 19091922.

Toggweiler JR, Russell JL, Carson SR. 2006. Midlatitude westerlies, atmospheric $\mathrm{CO}_{2}$, and climate change during the ice ages. Paleoceanography 21: 1-15.

Tonello MS, Mancini MV, Seppä H. 2009. Quantitative reconstruction of Holocene precipitation changes in southern Patagonia. Quaternary Research 72: 410-420.

Tonello MS, Prieto AR. 2008. Modern vegetation-pollen-climate relationships for the Pampa grasslands of Argentina. Journal of Biogeography 35: 926-938.

Villa-Martínez R, Moreno PI, Valenzuela MA. 2012. Deglacial and postglacial vegetation changes on the eastern slopes of the central Patagonian Andes $\left(47^{\circ} \mathrm{S}\right)$. Quaternary Science Reviews 32: 86-99. 


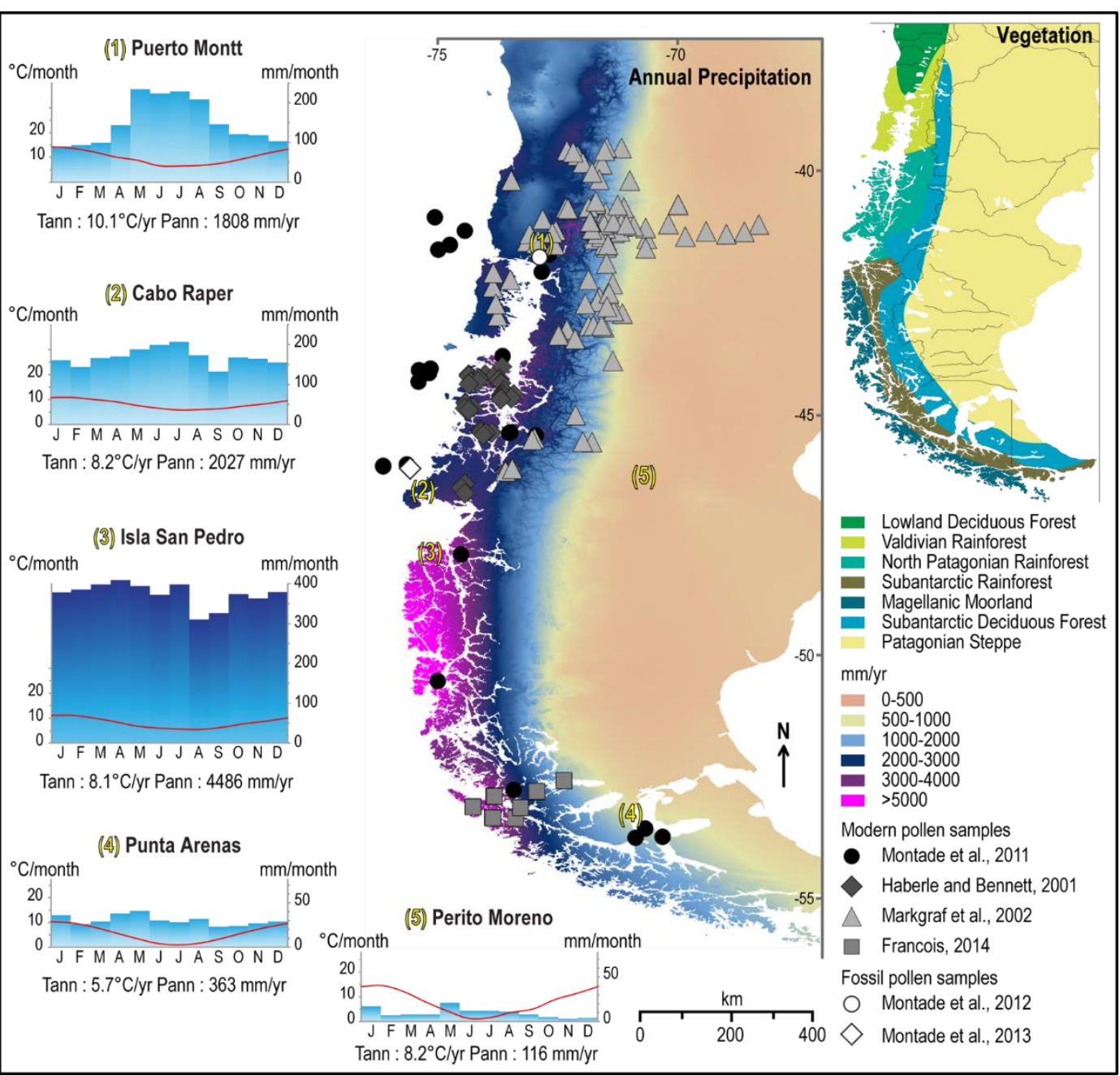

Figure 1. Climate and vegetation maps from Patagonia with location of modern samples and

683 fossil pollen records used in this study. Precipitation data were obtained from WorldClim 684 database (Hijmans et al., 2005), climatographs were performed using data from 685 meteorological stations (New_LocClim_1.10 software; Grieser et al., 2006) and vegetation 686 distribution is adapted from Schimithüsen (1956). 


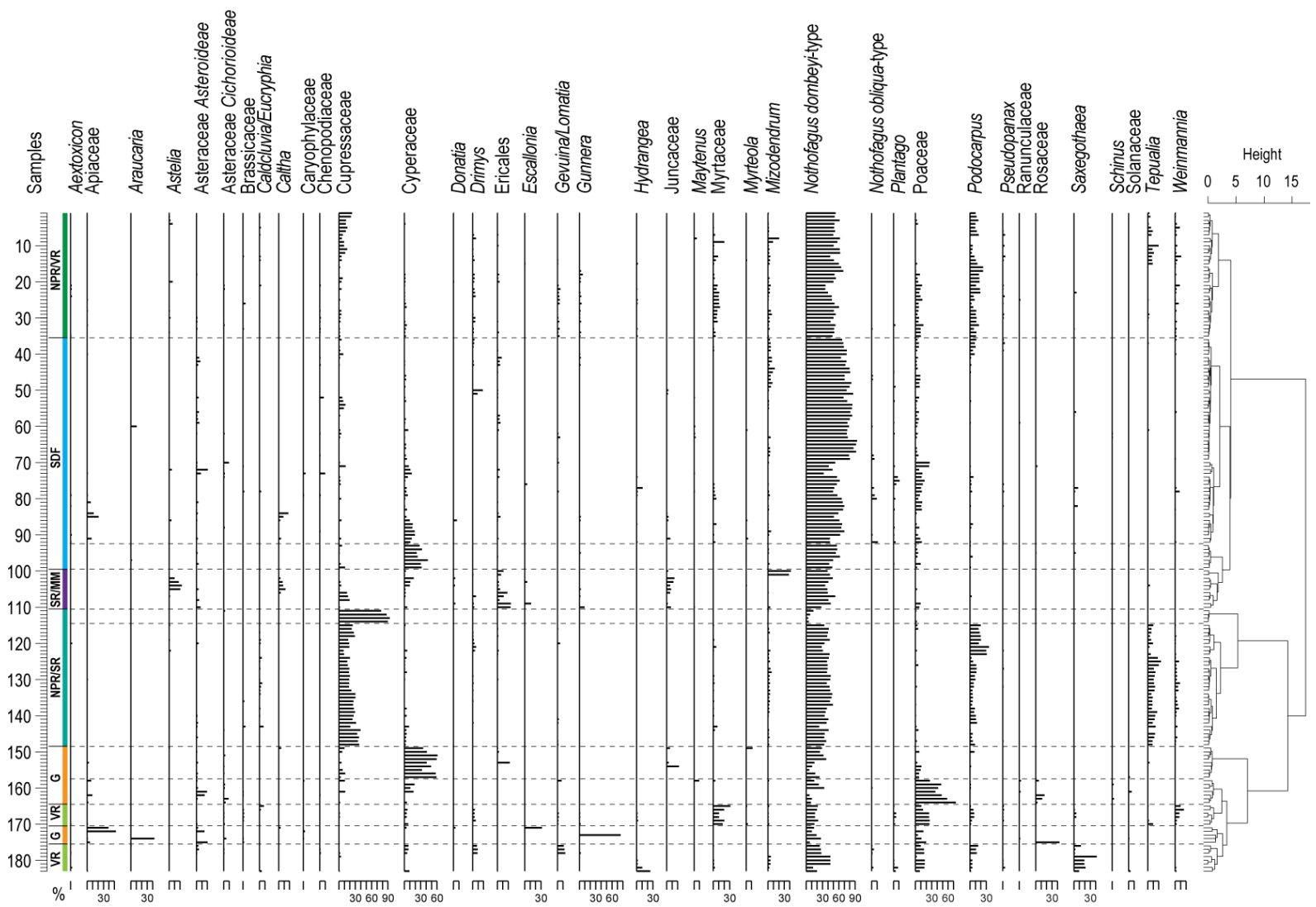
Figure 2. Pollen diagram of the 183 modern pollen samples from western Patagonia showing

690 the main pollen taxa. Ordination of modern pollen samples with pollen zones have been made 691 using a cluster analysis based on chord distance. According to the pollen assemblages of each 692 zone, six vegetation groups were identified: Grassland (G), Subantarctic Deciduous Forest 693 (SDF), Valdivian Rainforest (VR), North Patagonian/Valdivian Rainforest (NPR/VR), North 694 Patagonian/Subantarctic Rainforest (NPR/SR), Subantarctic Rainforest/Magellanic Moorland 695 (SR/MM). 


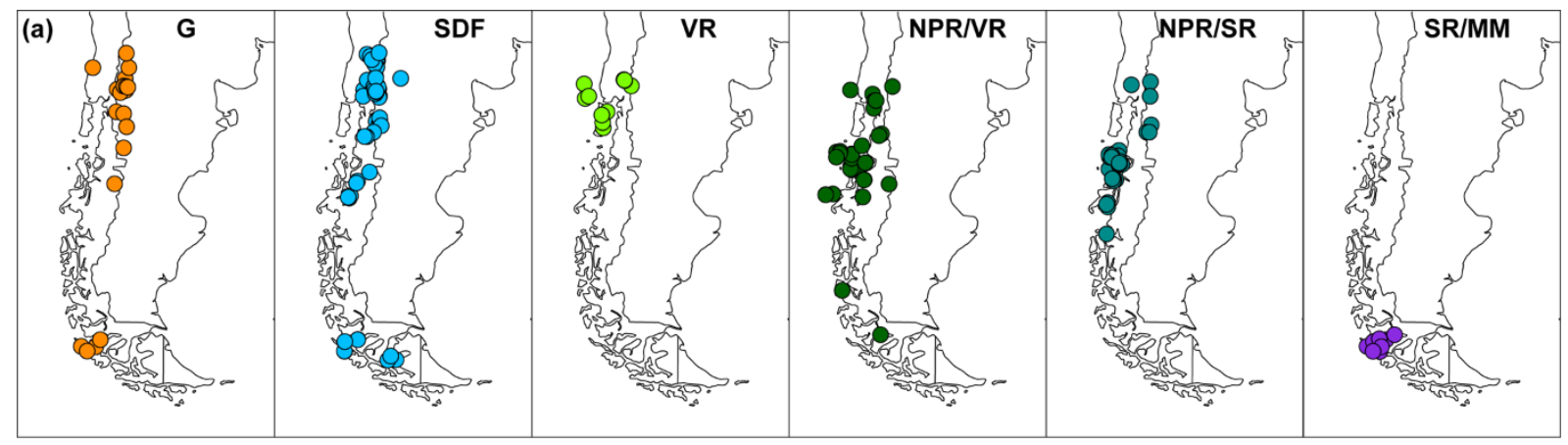

$\begin{array}{llllll}\text { (b) PANN mm } & \text { Psum mm DJF } & \text { P Win mm JJA } & \mathrm{T}_{\text {ANN }}{ }^{\circ} \mathrm{C} & \text { TSUM }^{\circ} \mathrm{C} \text { DJF } & \text { T }_{\text {WIN }}{ }^{\circ} \mathrm{C} \text { JJA }\end{array}$

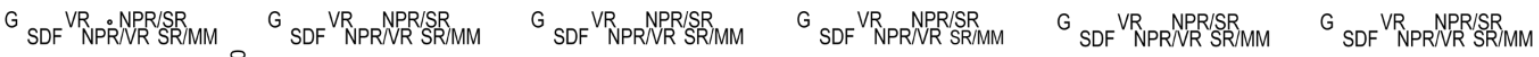
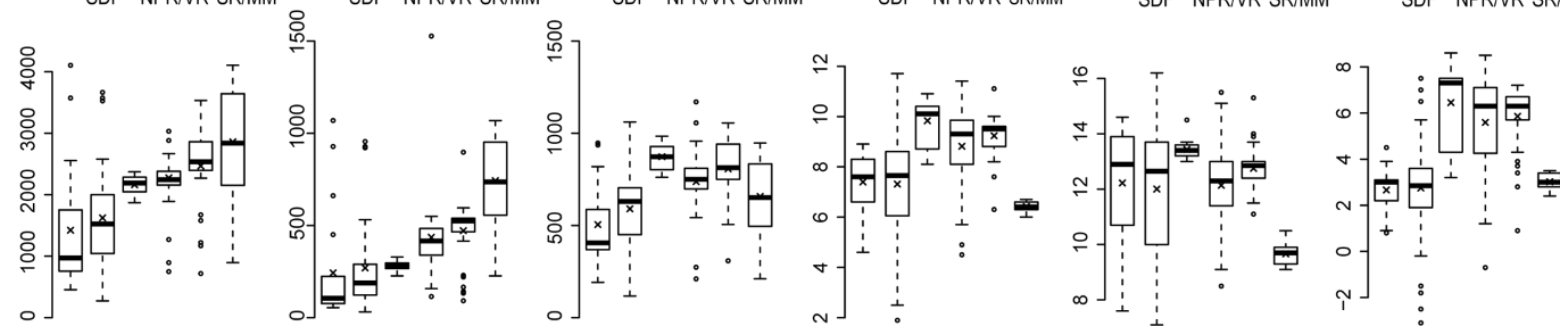

698 Figure 3. Distribution maps (a) of the 183 surface samples according to their respective

699 vegetation groups attributed from pollen assemblages: Grassland (G), Subantarctic Deciduous

700 Forest (SDF), Valdivian Rainforest (VR), North Patagonian/Valdivian Rainforest (NPR/VR),

701 North Patagonian/Subantarctic Rainforest (NPR/SR), Subantarctic Rainforest/Magellanic

702 Moorland (SR/MM). Boxplots (b) represent the main climate parameters of present-day

703 climate as they relate to the different vegetation groups: $\mathrm{P}_{\mathrm{ANN}}$ and $\mathrm{T}_{\mathrm{ANN}}$ correspond

704 respectively to the annual precipitation and the mean annual temperature, $\mathrm{P}_{\mathrm{SUM}}$ and $\mathrm{P}_{\mathrm{WIN}}$

705 correspond respectively to the precipitation sum of December-January-February and June-

706 July-August, $\mathrm{T}_{\mathrm{SUM}}$ and $\mathrm{T}_{\mathrm{WIN}}$ correspond to mean temperature of the same months as $\mathrm{P}_{\text {SUM }}$ and

$\mathrm{P}_{\mathrm{WIN}}$. The cross on each boxplot indicates the mean value for each climate parameter. 

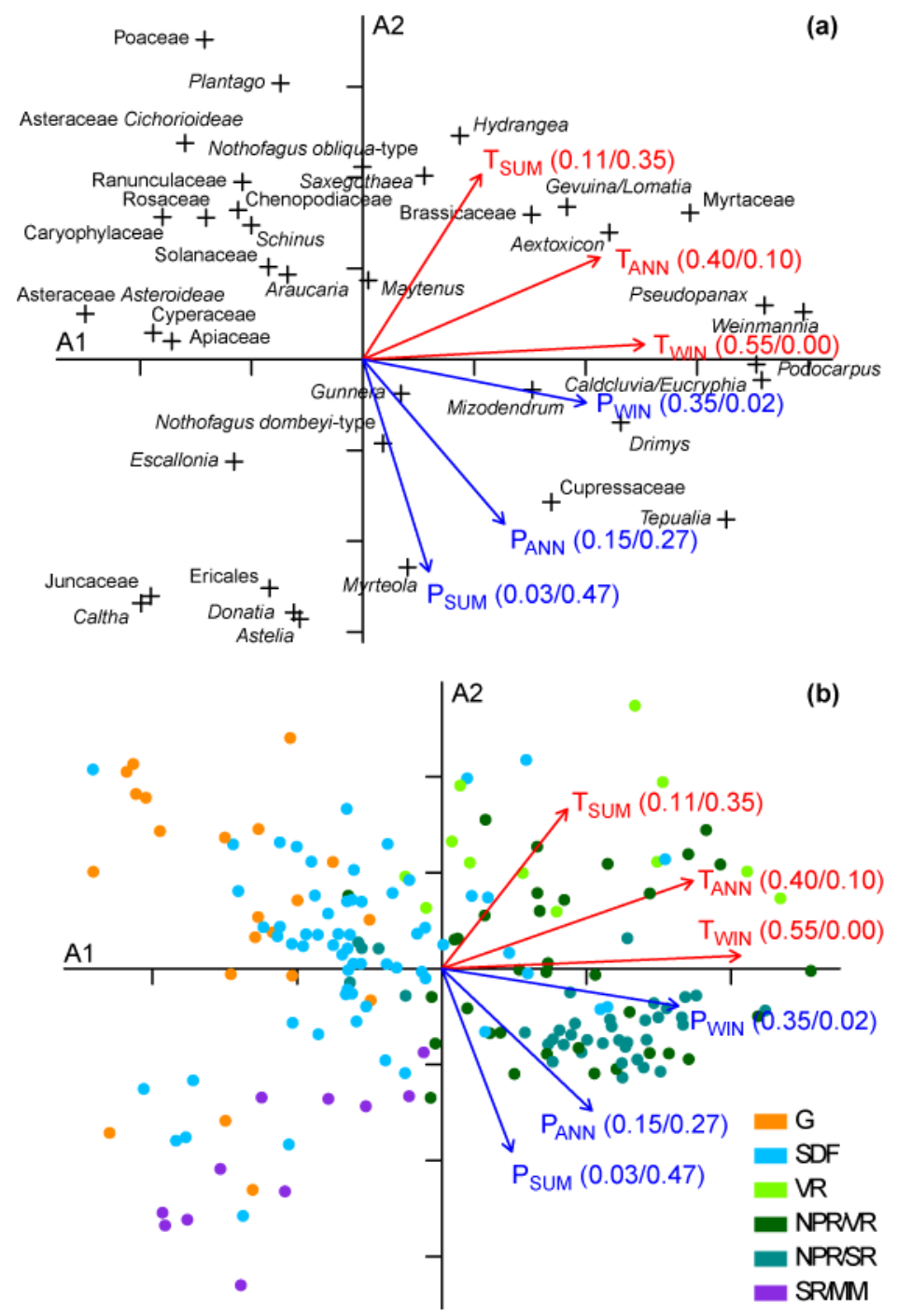

Figure 4. Bi-plot of the principal component analysis (PCA) with the 38 selected pollen taxa

711 (a) and the 183 selected modern pollen samples (b). Eigenvalues for the first and second axes 712 represent respectively $14 \%$ and $13 \%$ of the total variation. The arrows indicate the passive 713 climate parameter projected in the axes 1-2 bi-plot of the PCA with their respective $\mathrm{r}^{2}: \mathrm{P}_{\mathrm{ANN}}$ 714 and $\mathrm{T}_{\mathrm{ANN}}$ correspond respectively to the annual precipitation and the mean annual 715 temperature, $\mathrm{P}_{\mathrm{SUM}}$ and $\mathrm{P}_{\mathrm{WIN}}$ correspond respectively to the precipitation sum of December716 January-February and June-July-August, $\mathrm{T}_{\mathrm{SUM}}$ and $\mathrm{T}_{\mathrm{WIN}}$ correspond to mean temperature of 717 the same months as $\mathrm{P}_{\mathrm{SUM}}$ and $\mathrm{P}_{\mathrm{WIN}}$. Grassland $(\mathrm{G})$, Subantarctic Deciduous Forest (SDF), 718 Valdivian Rainforest (VR), North Patagonian/Valdivian Rainforest (NPR/VR), North 
719 Patagonian/Subantarctic Rainforest (NPR/SR), Subantarctic Rainforest/Magellanic Moorland 720 (SR/MM).


722 Figure 5. Comparison of predicted versus observed $\mathrm{P}_{\mathrm{SUM}}$ (precipitation sum of December-

723 January-February) and $\mathrm{T}_{\mathrm{WIN}}$ (mean temperature from June to August) performed on the 180

724 samples including oceanic and terrestrial pollen data from western Patagonia (excluding three

725 outliers) and using the Modern Analog Technique (MAT) and the Weighted Averaging Partial 726 Least Squares (WA-PLS). 


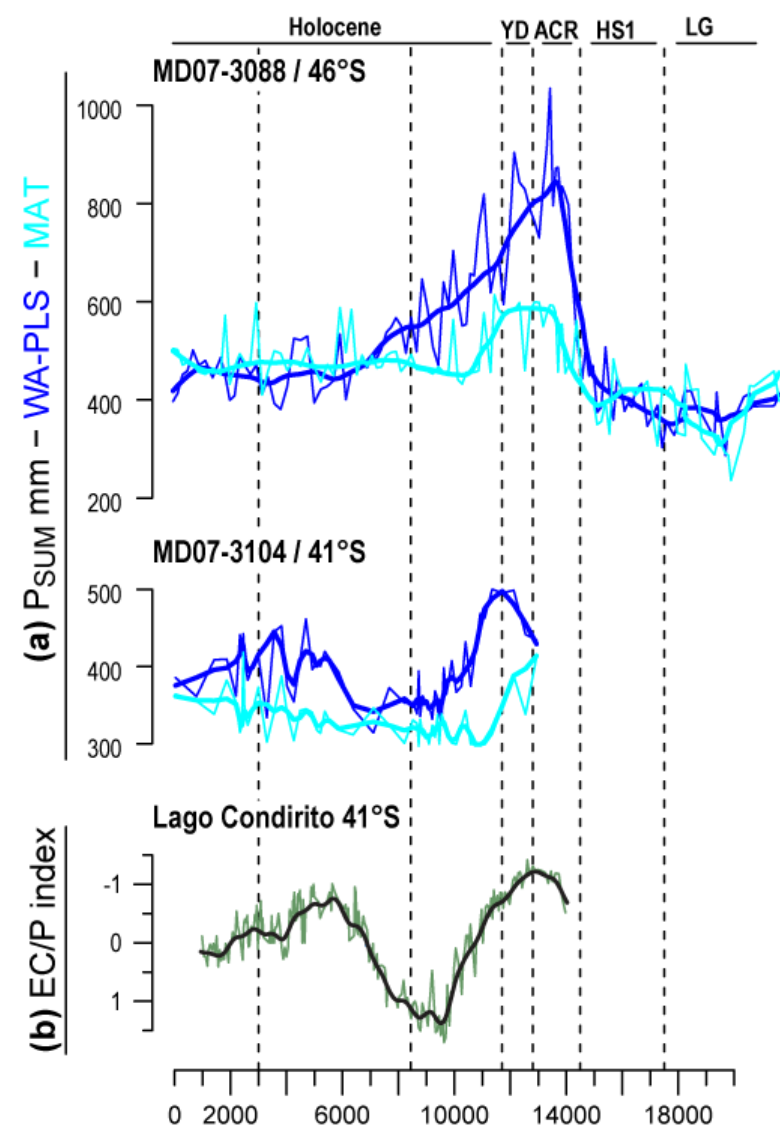

Age cal yr BP

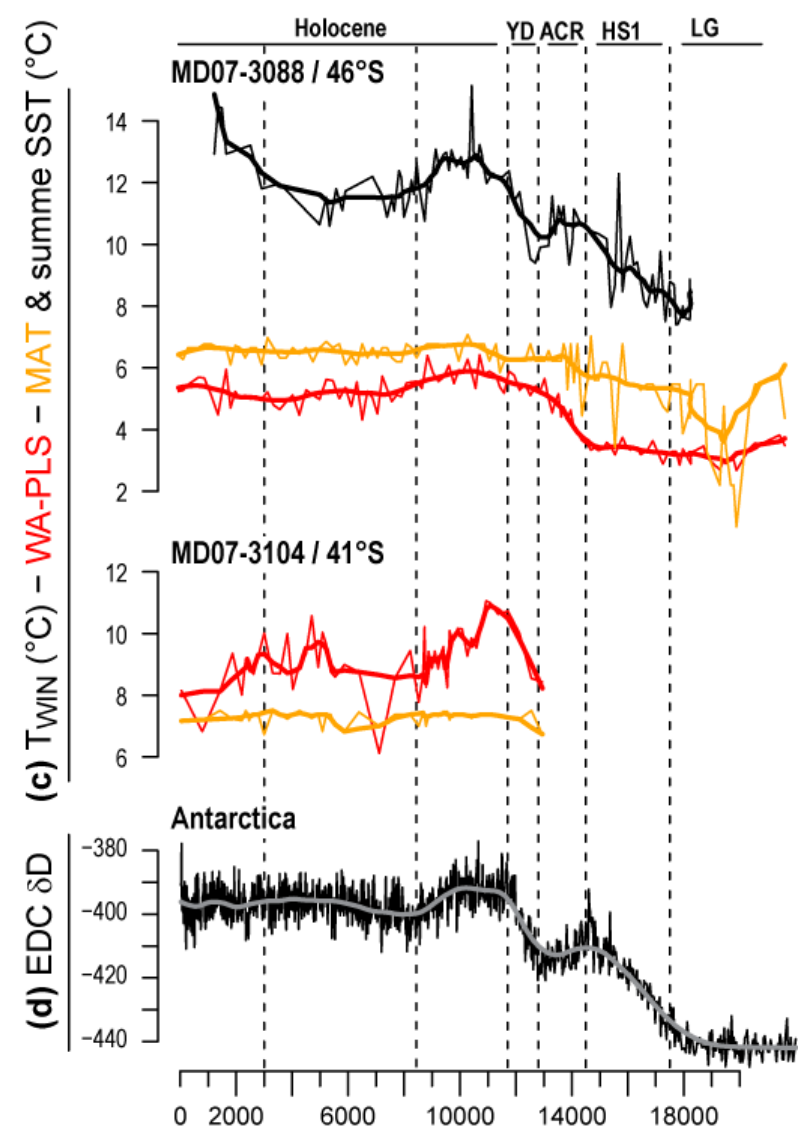

Age cal yr BP

729 Figure 6. Climate reconstructions from core MD07-3088 and core MD07-3104 compared

730 with independent palaeoclimatic proxies. The $\mathrm{P}_{\text {SUM }}$ (precipitation sum of December-January-

731 February) and $\mathrm{T}_{\text {WIN }}$ (mean temperature from June to August) have been reconstructed using

732 the MAT (Modern Analog Technique) and the WA-PLS (Weighted Averaging Partial Least

733 Squares) with the pollen-climate training set of 180 samples. (a) $\mathrm{P}_{\mathrm{SUM}}$ from core MD07-3088

734 and MD07-3104; (b) EC/P (Eucryphia-Caldcluvia/Podocarpus) index from Lago Condorito

735 (Moreno, 2004); (c) SSTs (Summer Sea Surface Temperatures) from core MD07-3088 based

736 on planktonic foraminifera assemblages (Siani et al., 2013) with $\mathrm{T}_{\mathrm{WIN}}$ from core MD07-3088

737 and MD07-3104; (d) Ice-core $\delta D$ based on the age scale of Lemieux-Dudon et al. (2010). The

738 original data were fit with a cubic smoothing spline (bold lines). YD, Younger Dryas; ACR,

739 Antarctic Cold Reversal; HS1, Heinrich Stadial 1; LGM, Last Glacial Maximum. 
741 Table 1. Performance of the Weighted Averaging Partial Least Squares (WA-PLS) and the

742 Modern Analog Technique (MAT) based on leave-one-out cross-validation with 183 and 180

743 samples including oceanic and terrestrial pollen data from western Patagonia ( $\mathrm{P}_{\text {SUM }}$,

744 precipitation sum of December-January-February; $\mathrm{T}_{\mathrm{WIN}}$, mean temperature from June to

745 August). The table indicate the best selected component for each parameter and cross-

746 validation test.

747

\begin{tabular}{|c|c|c|c|c|c|c|c|c|}
\hline Model & Component & Variables & Range & $\mathrm{r}^{2}$ & RMSEP & $\begin{array}{l}\text { RMSEP \% of } \\
\text { gradient }\end{array}$ & $\begin{array}{l}\text { Maximum } \\
\text { Bias }\end{array}$ & $\begin{array}{l}\text { Average } \\
\text { Bias }\end{array}$ \\
\hline MAT-183 & - & $\mathrm{P}_{\text {SUM }}$ & $31-1527 \mathrm{~mm}$ & 0.49 & 180.8 & 12.1 & 1035 & 17.50 \\
\hline WA-PLS-183 & 2 & $\mathrm{P}_{\mathrm{SUM}}$ & $31-1527 \mathrm{~mm}$ & 0.44 & 193.3 & 12.9 & 925 & 2.62 \\
\hline MAT-183 & - & $\mathrm{T}_{\mathrm{WIN}}$ & $-3.1-8.6^{\circ} \mathrm{C}$ & 0.77 & 1.1 & 20.3 & 2.1 & 2.08 \\
\hline WA-PLS-183 & 2 & $\mathrm{~T}_{\mathrm{WIN}}$ & $-3.1-8.6^{\circ} \mathrm{C}$ & 0.56 & 1.6 & 28.2 & 5.1 & -0.05 \\
\hline MAT-180 & - & $\mathrm{P}_{\text {SUM }}$ & $31-1069 \mathrm{~mm}$ & 0.54 & 162 & 15.6 & 446 & 17.31 \\
\hline WA-PLS-180 & 2 & $\mathrm{P}_{\text {SUM }}$ & $31-1069 \mathrm{~mm}$ & 0.53 & 164 & 15.8 & 266 & -0.28 \\
\hline MAT-180 & - & $\mathrm{T}_{\mathrm{WIN}}$ & $-3.1-8.6^{\circ} \mathrm{C}$ & 0.77 & 1.1 & 20.4 & 2.1 & -0.04 \\
\hline WA-PLS-180 & 2 & $\mathrm{~T}_{\mathrm{WIN}}$ & $-3.1-8.6^{\circ} \mathrm{C}$ & 0.55 & 1.6 & 28.5 & 5.1 & -0.05 \\
\hline
\end{tabular}


752 Figure S1. Comparison between observed and reconstructed present-day climate parameters 753 performed on the 24 modern oceanic pollen samples with the terrestrial pollen dataset 754 including 159 samples. The two climate parameters $\mathrm{P}_{\mathrm{SUM}}$ (precipitation sum of December755 January-February) and $\mathrm{T}_{\mathrm{WIN}}$ (mean temperature from June to August) are indicated from north 756 to south with their respective $\mathrm{r}^{2}$ between the observed and reconstructed values. MAT, 757 Modern Analog Technique; WA-PLS, Weighted Averaging Partial Least Squares.

Psum

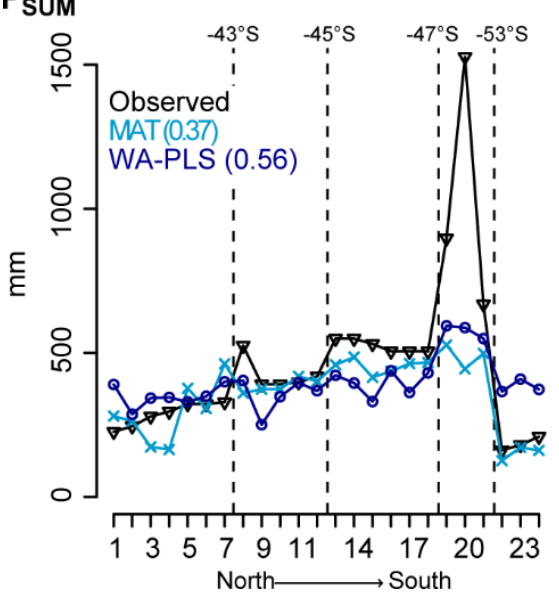

$T_{\text {WIN }}$

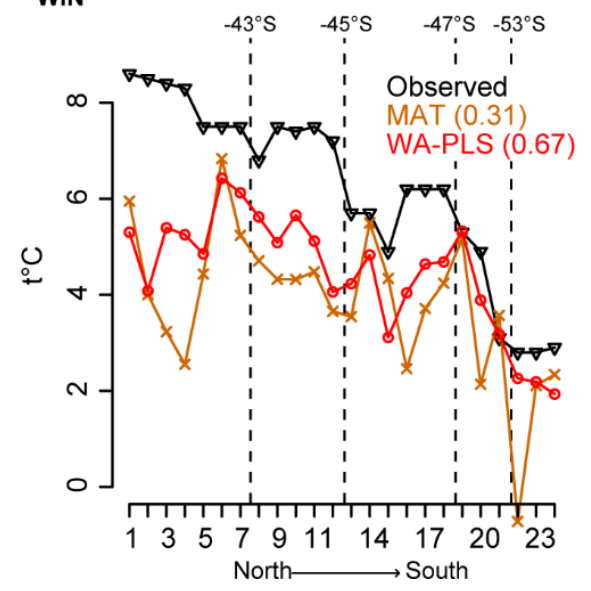


760 Figure S2. Comparison of predicted versus observed $\mathrm{P}_{\mathrm{SUM}}$ (precipitation sum of December-

761 January-February) and $\mathrm{T}_{\mathrm{WIN}}$ (mean temperature from June to August) performed on the 183

762 samples including oceanic and terrestrial pollen data from western Patagonia and using the

763 Modern Analog Technique (MAT) and the Weighted Averaging Partial Least Squares (WA-

764 PLS). Samples indicated in red correspond to the outliers identified from $\mathrm{P}_{\mathrm{SUM}}$ and removed

765 of the second 180-training set.
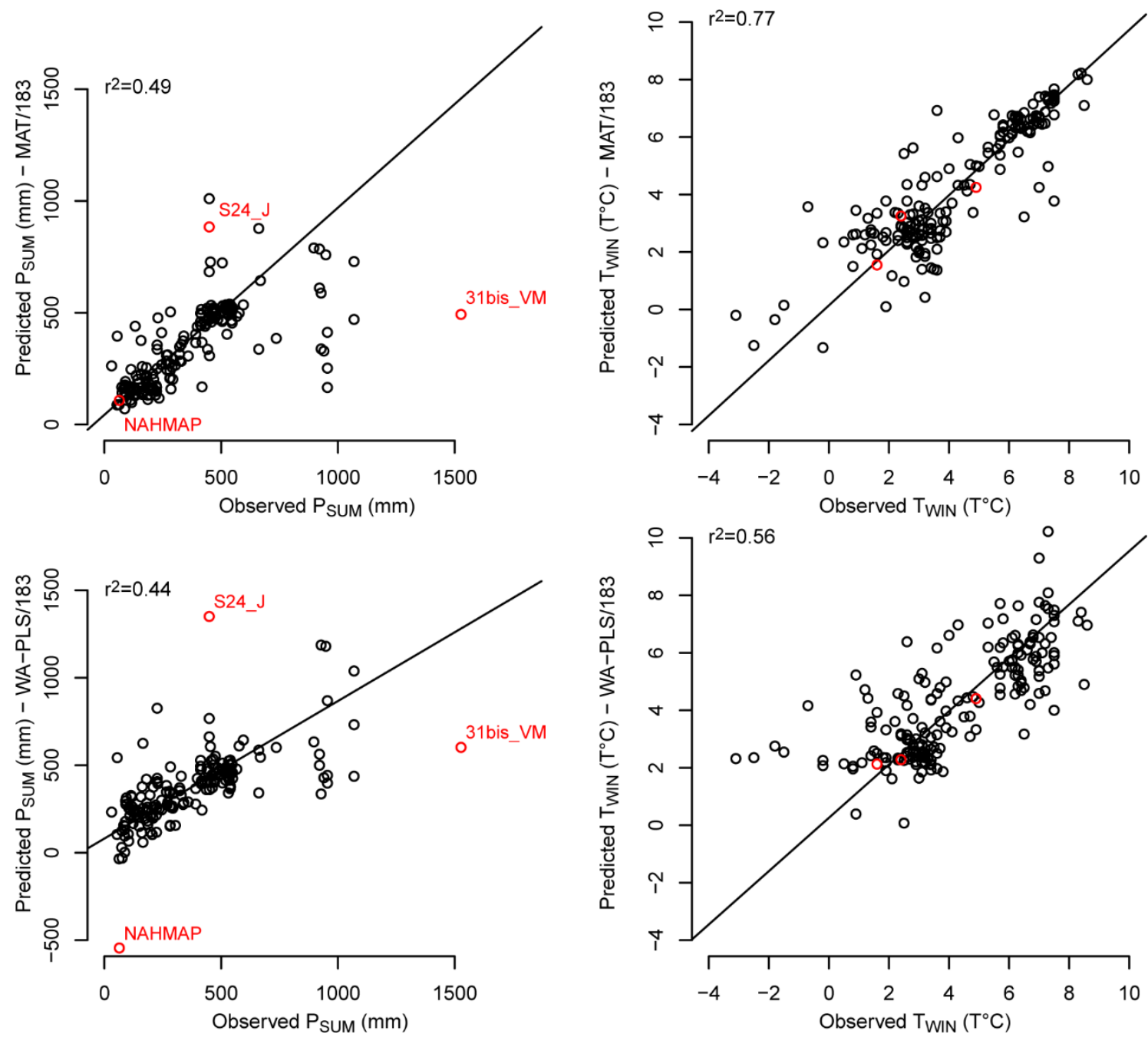
768 Figure S3. Effect of transfer function $r^{2}$ of deleting sites at random (mean of 10 trials; open 769 circles) and from the geographical and environmental neighbourhood of the test site (filled 770 circles and crosses) during cross-validation for the 180-training set. $\mathrm{P}_{\text {SUM }}$, precipitation sum of 771 December-January-February; $\mathrm{T}_{\mathrm{WIN}}$, mean temperature from June to August; MAT, Modern 772 Analog Technique; WA-PLS, Weighted Averaging Partial Least Squares.
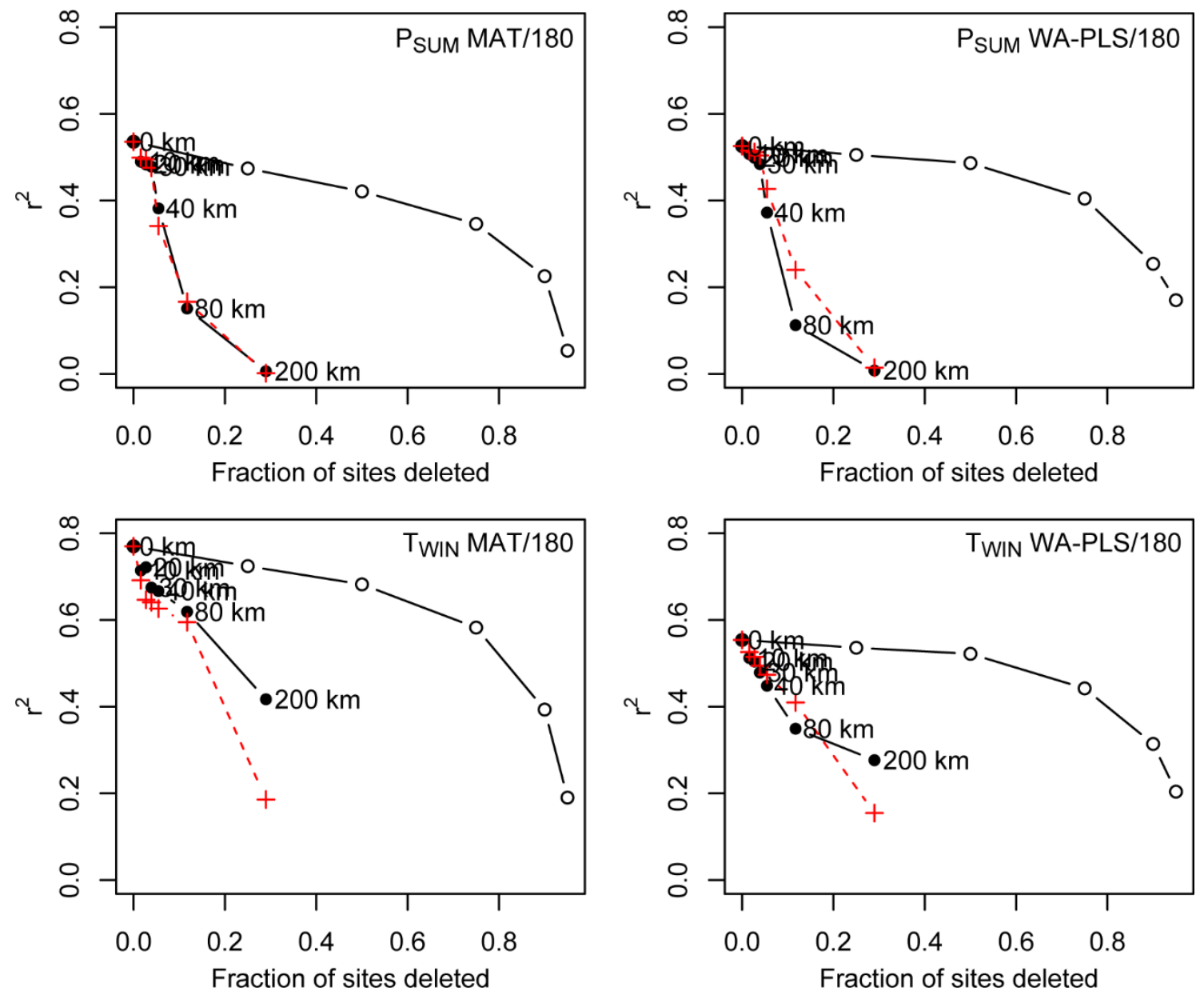
775 Table S1. List of the surface pollen samples from southern Patagonia according to their 776 location (Long., east longitude and Lat., north latitude) and altitude (m asl). The column 777 'code' indicate the order of samples in the pollen diagram perform by the cluster analysis 778 (samples without code correspond to samples excluded to perform statistical analyses). The 779 type correspond to oceanic (O), soil (S) and lake (L) samples. Reference (Ref.) to publication 7801 (Montade et al., 2011), 2 (Haberle and Bennett, 2001), 3 (Francois, 2014) and 4 (Markgraf 781 et al., 2002). Vegetation groups: Grassland (G), Subantarctic Deciduous Forest (SDF), 782 Valdivian Rainforest (VR), North Patagonian/Valdivian Rainforest (NPR/VR), North 783 Patagonian/Subantarctic Rainforest (NPR/SR), Subantarctic Rainforest/Magellanic Moorland 784 (SR/MM), Indeterminate (Ind).

\begin{tabular}{lccccccc}
\hline Name & Code & Type & Long. & Lat. & m asl & Ref. & Vegetation \\
\hline 7_VM & 28 & O & -76.1 & -46.07 & 0 & 1 & NPR/VR \\
8_VM & 30 & O & -76.1 & -46.08 & 0 & 1 & NPR/VR \\
11_VM & 34 & O & -75.37 & -44.33 & 0 & 1 & NPR/VR \\
12_VM & 24 & O & -75.36 & -44.09 & 0 & 1 & NPR/VR \\
13bis_VM & 31 & O & -75.15 & -44.15 & 0 & 1 & NPR/VR \\
14ter_VM & 33 & O & -74.41 & -41.21 & 0 & 1 & NPR/VR \\
15_VM & 176 & O & -75.03 & -40.93 & 0 & 1 & VR \\
16_VM & 177 & O & -74.96 & -41.6 & 0 & 1 & VR \\
17_VM & 178 & O & -74.72 & -41.5 & 0 & 1 & VR \\
18bis_VM & 21 & O & -72.78 & -41.71 & 0 & 1 & NPR/VR \\
19ter_VM & 35 & O & -72.67 & -41.7 & 0 & 1 & NPR/VR \\
20_VM & 22 & O & -72.82 & -42.06 & 0 & 1 & NPR/VR \\
21_VM & 25 & O & -75.12 & -44.06 & 0 & 1 & NPR/VR \\
22_VM & 23 & O & -73.63 & -43.8 & 0 & 1 & NPR/VR \\
23bis_VM & 19 & O & -73.47 & -45.38 & 0 & 1 & NPR/VR \\
24_VM & 29 & O & -73.49 & -45.39 & 0 & 1 & NPR/VR \\
26_VM & 39 & O & -72.94 & -45.44 & 0 & 1 & SDF \\
27_VM & 18 & O & -75.61 & -46.04 & 0 & 1 & NPR/VR \\
30_VM & 122 & O & -74.49 & -47.9 & 0 & 1 & NPR/SR \\
31bis_VM & 20 & O & -74.97 & -50.52 & 0 & 1 & NPR/VR \\
33_VM & 107 & O & -73.4 & -52.77 & 0 & 1 & SR/MM \\
36_VM & 42 & O & -70.88 & -53.76 & 0 & 1 & SDF \\
37_VM & 43 & O & -70.68 & -53.57 & 0 & 1 & SDF \\
38_VM & 41 & O & -70.32 & -53.74 & 0 & 1 & SDF \\
1_SH & 132 & L & -73.64 & -44.02 & 25 & 2 & NPR/SR \\
2_SH & 10 & L & -74.33 & -44.18 & 75 & 2 & NPR/VR \\
3_SH & 131 & L & -73.99 & -44.18 & 30 & 2 & NPR/SR
\end{tabular}




\begin{tabular}{|c|c|c|c|c|c|c|c|}
\hline 4_SH & 13 & $\mathrm{~L}$ & -74.33 & -44.21 & 75 & 2 & NPR/VR \\
\hline 5_SH & 136 & $\mathrm{~L}$ & -74.33 & -44.21 & 75 & 2 & NPR/SR \\
\hline 6_SH & 11 & $\mathrm{~L}$ & -74.33 & -44.21 & 75 & 2 & NPR/VR \\
\hline 7_SH & 127 & $\mathrm{~L}$ & -73.83 & -44.24 & 50 & 2 & NPR/SR \\
\hline 8_SH & 145 & $\mathrm{~L}$ & -74.13 & -44.25 & 49 & 2 & NPR/SR \\
\hline 9_SH & 128 & $\mathrm{~L}$ & -74.13 & -44.26 & 47 & 2 & NPR/SR \\
\hline 10_SH & 138 & $\mathrm{~L}$ & -73.69 & -44.27 & 75 & 2 & NPR/SR \\
\hline 11_SH & 133 & $\mathrm{~L}$ & -73.72 & -44.29 & 75 & 2 & NPR/SR \\
\hline 12_SH & 125 & $\mathrm{~L}$ & -73.72 & -44.29 & 75 & 2 & NPR/SR \\
\hline 13_SH & 124 & $\mathrm{~L}$ & -74.28 & -44.33 & 10 & 2 & NPR/SR \\
\hline 14_SH & 129 & $\mathrm{~L}$ & -74.29 & -44.33 & 10 & 2 & NPR/SR \\
\hline 15_SH & 146 & $\mathrm{~L}$ & -74.14 & -44.33 & 25 & 2 & NPR/SR \\
\hline 16_SH & 134 & $\mathrm{~L}$ & -73.66 & -44.36 & 50 & 2 & NPR/SR \\
\hline 17_SH & 137 & $\mathrm{~L}$ & -73.66 & -44.36 & 50 & 2 & NPR/SR \\
\hline 18_SH & 135 & $\mathrm{~L}$ & -73.66 & -44.36 & 50 & 2 & NPR/SR \\
\hline 19_SH & 12 & $\mathrm{~L}$ & -74.33 & -44.38 & 125 & 2 & NPR/VR \\
\hline 20_SH & 139 & $\mathrm{~L}$ & -73.6 & -44.52 & 76 & 2 & NPR/SR \\
\hline 21_SH & 14 & $\mathrm{~L}$ & -73.4 & -44.59 & 20 & 2 & NPR/VR \\
\hline 22_SH & 115 & $\mathrm{~L}$ & -73.65 & -44.59 & 30 & 2 & NPR/SR \\
\hline 23_SH & 147 & $\mathrm{~L}$ & -73.63 & -44.6 & 30 & 2 & NPR/SR \\
\hline 24_SH & 140 & $\mathrm{~L}$ & -73.6 & -44.63 & 20 & 2 & NPR/SR \\
\hline 25_SH & 126 & $\mathrm{~L}$ & -73.66 & -44.66 & 400 & 2 & NPR/SR \\
\hline 26_SH & 130 & $\mathrm{~L}$ & -73.45 & -44.67 & 25 & 2 & NPR/SR \\
\hline 27_SH & 3 & $\mathrm{~L}$ & -73.67 & -44.69 & 750 & 2 & NPR/VR \\
\hline 28_SH & 4 & $\mathrm{~L}$ & -73.67 & -44.69 & 770 & 2 & NPR/VR \\
\hline 29_SH & 1 & $\mathrm{~L}$ & -74.4 & -44.76 & 25 & 2 & NPR/VR \\
\hline 30_SH & 5 & $\mathrm{~L}$ & -74.39 & -44.78 & 25 & 2 & NPR/VR \\
\hline 31_SH & 6 & $\mathrm{~L}$ & -74.24 & -44.86 & 75 & 2 & NPR/VR \\
\hline 32_SH & 119 & $\mathrm{~L}$ & -74.33 & -44.88 & 25 & 2 & NPR/SR \\
\hline 33_SH & 7 & $\mathrm{~L}$ & -74.41 & -44.88 & 25 & 2 & NPR/VR \\
\hline 34_SH & 2 & $\mathrm{~L}$ & -74.33 & -44.92 & 75 & 2 & NPR/VR \\
\hline 35_SH & 148 & $\mathrm{~L}$ & -74.1 & -45.33 & 25 & 2 & NPR/SR \\
\hline 36_SH & 116 & $\mathrm{~L}$ & -74.08 & -45.33 & 125 & 2 & NPR/SR \\
\hline 37_SH & 117 & $\mathrm{~L}$ & -74.07 & -45.37 & 25 & 2 & NPR/SR \\
\hline 38_SH & 120 & $\mathrm{~L}$ & -73.85 & -45.38 & 25 & 2 & NPR/SR \\
\hline 39_SH & 141 & $\mathrm{~L}$ & -73.98 & -45.39 & 85 & 2 & NPR/SR \\
\hline 40_SH & 142 & $\mathrm{~L}$ & -74.03 & -45.43 & 25 & 2 & NPR/SR \\
\hline 41_SH & 36 & $\mathrm{~L}$ & -73.44 & -46.14 & 120 & 2 & SDF \\
\hline 42_SH & 16 & $\mathrm{~L}$ & -73.57 & -46.18 & 825 & 2 & NPR/VR \\
\hline 43_SH & 40 & $\mathrm{~L}$ & -73.58 & -46.19 & 675 & 2 & SDF \\
\hline 44_SH & 37 & $\mathrm{~L}$ & -73.51 & -46.23 & 75 & 2 & SDF \\
\hline 45_SH & 118 & $\mathrm{~L}$ & -74.41 & -46.44 & 25 & 2 & NPR/SR \\
\hline 46_SH & 123 & $\mathrm{~L}$ & -74.49 & -46.52 & 25 & 2 & NPR/SR \\
\hline 47_SH & 121 & $\mathrm{~L}$ & -74.41 & -46.64 & 25 & 2 & NPR/SR \\
\hline S38_J & 153 & $\mathrm{~S}$ & -74.24 & -53.12 & 2 & 3 & G \\
\hline S39(2)_J & 102 & $S$ & -74.24 & -53.12 & 78 & 3 & SR/MM \\
\hline
\end{tabular}




\begin{tabular}{|c|c|c|c|c|c|c|c|}
\hline S39(1)_J & 103 & $\mathrm{~S}$ & -74.24 & -53.12 & 78 & 3 & SR/MM \\
\hline S32_J & 171 & $\mathrm{~S}$ & -73.84 & -53.34 & 378 & 3 & G \\
\hline S29_J & 109 & $\mathrm{~S}$ & -73.83 & -53.35 & 2 & 3 & SR/MM \\
\hline S31_J & 72 & $S$ & -73.84 & -53.34 & 324 & 3 & SDF \\
\hline S30_J & 61 & $\mathrm{~S}$ & -73.83 & -53.35 & 70 & 3 & SDF \\
\hline S28_J & 50 & $\mathrm{~S}$ & -73.83 & -53.35 & 12 & 3 & SDF \\
\hline S34_J & 100 & $\mathrm{~S}$ & -73.36 & -53.36 & 26 & 3 & SR/MM \\
\hline S16_J & 84 & $\mathrm{~S}$ & -73.81 & -52.9 & 290 & 3 & SDF \\
\hline S9_J & 104 & $\mathrm{~S}$ & -73.8 & -52.91 & 30 & 3 & SR/MM \\
\hline S21_J & 91 & $\mathrm{~S}$ & -73.81 & -52.9 & 256 & 3 & SDF \\
\hline S4_J & 101 & $\mathrm{~S}$ & -73.8 & -52.9 & 155 & 3 & SR/MM \\
\hline S36_J & 149 & $\mathrm{~S}$ & -73.26 & -53.14 & 6 & 3 & G \\
\hline S35_J & 108 & $\mathrm{~S}$ & -73.26 & -53.14 & 30 & 3 & SR/MM \\
\hline S25_J & 85 & $\mathrm{~S}$ & -72.94 & -52.81 & 411 & 3 & SDF \\
\hline S24_J & 105 & $\mathrm{~S}$ & -72.93 & -52.81 & 90 & 3 & SR/MM \\
\hline S26_J & 106 & $\mathrm{~S}$ & -72.93 & -52.81 & 13 & 3 & SR/MM \\
\hline S23_J & 86 & $\mathrm{~S}$ & -72.93 & -52.81 & 22 & 3 & SDF \\
\hline S42_J & 173 & S & -72.94 & -52.81 & 53 & 3 & G \\
\hline S27_J & 51 & $\mathrm{~S}$ & -72.92 & -52.8 & 12 & 3 & SDF \\
\hline S41_J & 110 & $\mathrm{~S}$ & -72.36 & -52.58 & 4 & 3 & SR/MM \\
\hline S40_J & 8 & $\mathrm{~S}$ & -72.36 & -52.58 & 14 & 3 & NPR/VR \\
\hline AGUICER & 74 & $\mathrm{~S}$ & -72.12 & -45.02 & 270 & 4 & SDF \\
\hline ALEBOG & 15 & $\mathrm{~S}$ & -72.9 & -41.4 & 100 & 4 & NPR/VR \\
\hline ALEMIT & 70 & $\mathrm{~S}$ & -71.42 & -42.58 & 1000 & 4 & SDF \\
\hline ALENOR & 54 & $\mathrm{~S}$ & -71.63 & -42.58 & 800 & 4 & SDF \\
\hline ANGOST & 111 & $\mathrm{~S}$ & -71.5 & -40.83 & 800 & 4 & NPR/SR \\
\hline ANTILL & 82 & $\mathrm{~S}$ & -72.28 & -40.75 & 730 & 4 & SDF \\
\hline AUSESQ & 112 & $\mathrm{~S}$ & -71.45 & -42.83 & 1100 & 4 & NPR/SR \\
\hline BAYAS & & $\mathrm{S}$ & -70.65 & -41.37 & 1100 & 4 & G \\
\hline CANAMOS & 62 & $\mathrm{~S}$ & -71.48 & -41.55 & 700 & 4 & SDF \\
\hline CARILAF & 79 & $\mathrm{~S}$ & -71.63 & -39.83 & 875 & 4 & SDF \\
\hline CASOVE & 151 & $\mathrm{~S}$ & -71.8 & -41.18 & 870 & 4 & G \\
\hline CERDIE15 & 57 & $\mathrm{~S}$ & -71.65 & -41.3 & 1500 & 4 & SDF \\
\hline CERDIE17 & 81 & $\mathrm{~S}$ & -71.65 & -41.3 & 1750 & 4 & SDF \\
\hline CERDIE18 & 56 & $\mathrm{~S}$ & -71.65 & -41.3 & 1800 & 4 & SDF \\
\hline CEZARE & 95 & $\mathrm{~S}$ & -71.67 & -41.3 & 1150 & 4 & SDF \\
\hline CHALL & 152 & $\mathrm{~S}$ & -71.32 & -41.25 & 1250 & 4 & G \\
\hline CHEQUE & & $\mathrm{S}$ & -70.67 & -41.57 & 1400 & 4 & G \\
\hline CHILBORD & 48 & $\mathrm{~S}$ & -71.75 & -40.67 & 1000 & 4 & SDF \\
\hline COLOP & 64 & $\mathrm{~S}$ & -71.57 & -41.1 & 1500 & 4 & SDF \\
\hline COMALLO & & $\mathrm{S}$ & -70.2 & -41.07 & 815 & 4 & G \\
\hline CONDOR & & $\mathrm{S}$ & -71.15 & -41.12 & 800 & 4 & SR/MM \\
\hline CONFLUEN & & $\mathrm{S}$ & -71.12 & -40.73 & 690 & 4 & SR/MM \\
\hline DDTRELA & 98 & $\mathrm{~S}$ & -71.7 & -40.65 & 850 & 4 & SDF \\
\hline ELTEPU & & $\mathrm{S}$ & -73.13 & -41.43 & 100 & 4 & SR/MM \\
\hline EPUYZ & 163 & $S$ & -71.35 & -42.31 & 800 & 4 & G \\
\hline
\end{tabular}




\begin{tabular}{|c|c|c|c|c|c|c|c|}
\hline ESPERA & 159 & S & -71.85 & -42.22 & 550 & 4 & G \\
\hline ESQAER & 172 & S & -71.15 & -42.92 & 780 & 4 & G \\
\hline ESTGRA & & S & -70.67 & -41.15 & 980 & 4 & G \\
\hline FARWES & 156 & S & -71.2 & -41.22 & 800 & 4 & G \\
\hline FUTALE1 & & $\mathrm{S}$ & -71.53 & -43.2 & 380 & 4 & G \\
\hline FUTALE2 & 75 & S & -71.85 & -43.17 & 330 & 4 & SDF \\
\hline FUTBOR & 113 & S & -71.75 & -43.17 & 490 & 4 & NPR/SR \\
\hline GUALALA & 77 & S & -72.08 & -39.65 & 450 & 4 & SDF \\
\hline INGJAC1 & & $\mathrm{S}$ & -69 & -41.28 & 870 & 4 & G \\
\hline INGJAC2 & & $\mathrm{S}$ & -69.85 & -41.33 & 960 & 4 & G \\
\hline LANQUIH & 143 & $\mathrm{~S}$ & -72.8 & -40.97 & 150 & 4 & NPR/SR \\
\hline LANQUIV & 76 & S & -72.53 & -41.2 & 66 & 4 & SDF \\
\hline LAOLAO & 44 & S & -71.55 & -41.05 & 765 & 4 & SDF \\
\hline LAUFCH & & S & -69.42 & -41.22 & 800 & 4 & G \\
\hline LAZETA & 164 & $\mathrm{~S}$ & -71.35 & -43.9 & 760 & 4 & G \\
\hline LGNVER & 68 & $\mathrm{~S}$ & -71.57 & -39.83 & 400 & 4 & SDF \\
\hline LGOCAM & 45 & S & -71.85 & -40.72 & 1000 & 4 & SDF \\
\hline LGOCAS & 32 & S & -71.78 & -45.58 & 1000 & 4 & NPR/VR \\
\hline LGOCC & 17 & S & -73.57 & -46.18 & 820 & 4 & NPR/VR \\
\hline LGOCOR1 & 65 & S & -71.7 & -40.6 & 810 & 4 & SDF \\
\hline LGOCOR2 & 73 & $\mathrm{~S}$ & -71.33 & -42.87 & 750 & 4 & SDF \\
\hline LGOESP & 182 & $\mathrm{~S}$ & -72.32 & -40.73 & 525 & 4 & VR \\
\hline LGOFON & 66 & S & -71.75 & -41.35 & 750 & 4 & SDF \\
\hline LGOGAL & 83 & $\mathrm{~S}$ & -70 & -40.67 & 950 & 4 & SDF \\
\hline LGOGUI & & $\mathrm{S}$ & -71.48 & -41.42 & 950 & 4 & SR/MM \\
\hline LGOHES & 88 & $\mathrm{~S}$ & -71.73 & -41.38 & 740 & 4 & SDF \\
\hline LGOLAR & 63 & $\mathrm{~S}$ & -71.67 & -42.67 & 750 & 4 & SDF \\
\hline LGOMAL & 87 & $\mathrm{~S}$ & -72.33 & -43.38 & 1000 & 4 & SDF \\
\hline LGOMIR & 38 & $\mathrm{~S}$ & -73.43 & -46.13 & 115 & 4 & SDF \\
\hline LGOMOR & 144 & $\mathrm{~S}$ & -71.52 & -41.5 & 800 & 4 & NPR/SR \\
\hline LGOMOS & 71 & $\mathrm{~S}$ & -71.43 & -42.5 & 600 & 4 & SDF \\
\hline LGONELT & 92 & $\mathrm{~S}$ & -71.97 & -39.8 & 200 & 4 & SDF \\
\hline LGOPAS & 165 & $\mathrm{~S}$ & -73.83 & -42.37 & 150 & 4 & VR \\
\hline LGOPAT & & $\mathrm{S}$ & -70 & -40.67 & 950 & 4 & Ind \\
\hline LGOPID & & $\mathrm{S}$ & -73.07 & -41.27 & 170 & 4 & G \\
\hline 1GOPOP & 169 & $\mathrm{~S}$ & -73.47 & -42.22 & 115 & 4 & VR \\
\hline LGORIE & & $\mathrm{S}$ & -72.97 & -45.5 & 250 & 4 & G \\
\hline LGOSAR & 78 & $\mathrm{~S}$ & -72.56 & -41.5 & 400 & 4 & SDF \\
\hline LGOSCH & 58 & $\mathrm{~S}$ & -71.5 & -41.16 & 2100 & 4 & SDF \\
\hline LGOTAR1 & 167 & $\mathrm{~S}$ & -73.77 & -42.72 & 100 & 4 & VR \\
\hline LGOTAR2 & 168 & $\mathrm{~S}$ & -73.77 & -42.72 & 100 & 4 & VR \\
\hline LGOTOR1 & 180 & $\mathrm{~S}$ & -72.27 & -40.77 & 700 & 4 & VR \\
\hline LGOTOR2 & 181 & $\mathrm{~S}$ & -72.27 & -40.77 & 700 & 4 & VR \\
\hline LGOTRO & 59 & $\mathrm{~S}$ & -71.5 & -41.16 & 2000 & 4 & SDF \\
\hline LGOVEN1 & 46 & $\mathrm{~S}$ & -71.67 & -41.22 & 825 & 4 & SDF \\
\hline LGOVEN2 & 49 & $\mathrm{~S}$ & -73.02 & -45.53 & 650 & 4 & SDF \\
\hline
\end{tabular}




\begin{tabular}{|c|c|c|c|c|c|c|c|}
\hline LGOVEN3 & 47 & $S$ & -71.67 & -41.22 & 825 & 4 & SDF \\
\hline LGOYEL & 26 & $S$ & -72.3 & -43.25 & 546 & 4 & NPR/VR \\
\hline LLAOL & 9 & $S$ & -71.55 & -41.05 & 850 & 4 & NPR/VR \\
\hline LOSCLAR & 89 & $S$ & -71.82 & -41.03 & 1100 & 4 & SDF \\
\hline LOSMENU & & $S$ & -68.33 & -41.08 & 840 & 4 & G \\
\hline MALBOO & 157 & $S$ & -71.58 & -41.33 & 800 & 4 & G \\
\hline MALLIN & 183 & $S$ & -72.28 & -40.75 & 750 & 4 & VR \\
\hline MALLINAU & 99 & $S$ & -71.68 & -41.27 & 900 & 4 & SDF \\
\hline MALSON & 93 & $S$ & -71.53 & -41.08 & 800 & 4 & SDF \\
\hline MAQUIN & & $S$ & -68.63 & -41.23 & 870 & 4 & G \\
\hline MASCAR & 52 & $\mathrm{~S}$ & -71.67 & -41.27 & 800 & 4 & SDF \\
\hline MATAMOL & 161 & $\mathrm{~S}$ & -71 & -40.17 & 1100 & 4 & G \\
\hline MAUSTR & 27 & $S$ & -72.47 & -43.33 & 600 & 4 & NPR/VR \\
\hline MELLIZ & & $S$ & -70 & -40.67 & 950 & 4 & Ind \\
\hline MIRABJ & 160 & $\mathrm{~S}$ & -73.45 & -40.17 & 750 & 4 & G \\
\hline MIRADOR & 150 & $S$ & -73.45 & -40.17 & 850 & 4 & G \\
\hline MONTHU & 80 & $S$ & -71.63 & -40.15 & 640 & 4 & SDF \\
\hline MYELCH & 96 & $S$ & -72.47 & -43.37 & 1000 & 4 & SDF \\
\hline NAHHUA & 162 & $\mathrm{~S}$ & -71.17 & -41.05 & 810 & 4 & G \\
\hline NAHMAP & 174 & $\mathrm{~S}$ & -71.17 & -39.5 & 1500 & 4 & G \\
\hline NAHUH & 158 & $\mathrm{~S}$ & -71.34 & -41.03 & 830 & 4 & G \\
\hline NANTY & 114 & $\mathrm{~S}$ & -71.58 & -43.17 & 530 & 4 & NPR/SR \\
\hline NOTESQ & 67 & $\mathrm{~S}$ & -71.47 & -42.78 & 1180 & 4 & SDF \\
\hline PAMTOR & 55 & $\mathrm{~S}$ & -71.45 & -41.5 & 1000 & 4 & SDF \\
\hline PANQHUE & 90 & S & -71.78 & -40 & 1100 & 4 & SDF \\
\hline PASTAHU & 170 & $\mathrm{~S}$ & -73.83 & -42.37 & 150 & 4 & VR \\
\hline PEDREG & 154 & $\mathrm{~S}$ & -71.97 & -45.57 & 550 & 4 & G \\
\hline PILCAN & & $\mathrm{S}$ & -70.92 & -41.11 & 1000 & 4 & G \\
\hline PRIMAV & 155 & $\mathrm{~S}$ & -71.25 & -40.68 & 800 & 4 & G \\
\hline PRTMON & & $S$ & -72.93 & -41.47 & 100 & 4 & G \\
\hline PSOTROM & 97 & $\mathrm{~S}$ & -71.48 & -39.48 & 11.96 & 4 & SDF \\
\hline PTOBLES & 53 & $S$ & -71.8 & -41.03 & 760 & 4 & SDF \\
\hline PTOCAFE & & $\mathrm{S}$ & -71.92 & -42.72 & 550 & 4 & SR/MM \\
\hline PTORAM & & $\mathrm{S}$ & -72.13 & -43.45 & 300 & 4 & G \\
\hline QUILLEH & 60 & $\mathrm{~S}$ & -71.52 & -39.55 & 1104 & 4 & SDF \\
\hline REPOL & & $\mathrm{S}$ & -71.48 & -41.88 & 500 & 4 & SR/MM \\
\hline RINCON & 175 & $\mathrm{~S}$ & -71.07 & -41.08 & 580 & 4 & G \\
\hline RIOALER & 94 & S & -71.78 & -41.18 & 850 & 4 & SDF \\
\hline RIOFRI & 179 & $\mathrm{~S}$ & -71.82 & -41.02 & 850 & 4 & VR \\
\hline RIONEG & & $S$ & -73.82 & -42.08 & 60 & 4 & SR/MM \\
\hline RIOTEP & & $S$ & -72.6 & -41.25 & 70 & 4 & G \\
\hline RUCANAN & 69 & $\mathrm{~S}$ & -72.3 & -39.55 & 290 & 4 & SDF \\
\hline SANANTO & 166 & $\mathrm{~S}$ & -73.73 & -42.97 & 150 & 4 & VR \\
\hline TARAHUB & & $S$ & -73.77 & -42.72 & 100 & 4 & G \\
\hline TRALCAP & & $S$ & -72.17 & -39.58 & 230 & 4 & G \\
\hline
\end{tabular}


786 Table S2. List of the 78 pollen taxa.

\begin{tabular}{ll}
\hline Family & Taxa name \\
\hline Rosaceae & Acaena \\
Fabaceae & Adesmia \\
Aextoxicaceae & Aextoxicon \\
Apiaceae & Apiaceae \\
Araucariaceae & Araucaria \\
Elaeocarpaceae & Aristotelia \\
Asteraceae & Artemisia \\
Asteliaceae & Astelia \\
Asteraceae & Asteraceae Asteroideae \\
Asteraceae & Asteraceae Cichorioideae \\
Flacourtiaceae & Azara \\
Berberidaceae & Berberis \\
Boraginaceae & Boraginaceae \\
Brassicaceae & Brassicaceae \\
Buddlejaceae & Buddleja \\
Scrophulariaceae & Calceolaria \\
Cunoniaceae & Caldcluvia/Eucryphia \\
Ranunculaceae & Caltha \\
Caryophylaceae & Caryophylaceae \\
Chenopodiaceae & Chenopodiaceae \\
Cupressaceae & Cupressaceae \\
Cyperaceae & Cyperaceae \\
Podocarpaceae & Dacrydium \\
Columelliaceae & Desfontainia \\
Stylidiaceae & Donatia \\
Winteraceae & Drimys \\
Proteaceae & Embothrium \\
Ephedraceae & Ephedra \\
Ericales & Ericales \\
Escalloniaceae & Escallonia \\
Euphorbiaceae & Euphorbiaceae \\
Fabaceae & Fabaceae \\
Gentianaceae & Gentianaceae \\
Geraniaceae & Geraniaceae \\
Proteaceae & Gevuina/Lomatia \\
Griseliniaceae & Griselinia \\
Gunneraceae & Gunnera \\
Hydrangeaceae & Hydrangea \\
Hydrophylaceae & Hydrophylaceae \\
Juncaceae & Juncaceae \\
Santalaceae & Lepidoceras \\
Philesiaceae & Luzuriaga \\
Celastraceae & Maytenus \\
&
\end{tabular}




\begin{tabular}{ll} 
Misodendraceae & Misodendrum \\
Apiaceae & Mulinum \\
Myrtaceae & Myrtaceae \\
Myrtaceae & Myrteola \\
Nothofagaceae & Nothofagus dombeyi-type \\
Nothofagaceae & Nothofagus obliqua-type \\
Onagraceae & Onagraceae \\
Thymelaeaceae & Ovidia \\
Hydrophyllaceae & Phacelia \\
Philesiaceae & Philesia \\
Plantaginaceae & Plantago \\
Poaceae & Poaceae \\
Podocarpaceae & Podocarpus \\
Polygonaceae & Polygonaceae \\
Primulaceae & Primulaceae \\
Araliaceae & Pseudopanax \\
Ranunculaceae & Ranunculaceae \\
Rhamnaceae & Rhamnaceae \\
Verbenaceae & Rhaphithamnus \\
Grossulariaceae & Ribes \\
Rosaceae & Rosaceae \\
Rubiaceae & Rubiaceae \\
Polygonaceae & Rumex \\
Salicaceae & Salix \\
Sapindaceae & Sapindaceae \\
Podocarpaceae & Saxegothaea \\
Saxifragaceae & Saxifragaceae \\
Anacardiaceae & Schinus \\
Scrophulariaceae & Scrophulariaceae \\
Solanaceae & Solanaceae \\
Myrtaceae & Tepualia \\
Urticaceae & Urtica \\
Valerianaceae & Valerianaceae \\
Verbenaceae & Verbenaceae \\
Cunoniaceae & Weinmannia \\
\hline &
\end{tabular}

